Love and Cinema- Cinephilia, Style, and the Films of Quentin Tarantino

by

\title{
Matthew Harris
}

A (thesis) submitted to the Faculty of

Graduate Studies and Research in partial fulfillment

of the requirements for the degree of

Master of Arts

in Film Studies

Carleton University

OTTAWA, Ontario

Tuesday, January 4

2011, Matthew Harris 
Library and Archives

Canada

Published Heritage Branch

395 Wellington Street

Ottawa ON K1A ON4

Canada
Bibliothèque et

Archives Canada

Direction du

Patrimoine de l'édition

395 , rue Wellington

Ottawa ON K1A ON4

Canada
Your file Votre référence

ISBN: 978-0-494-79566-8

Our file Notre référence

ISBN: 978-0-494-79566-8
NOTICE:

The author has granted a nonexclusive license allowing Library and Archives Canada to reproduce, publish, archive, preserve, conserve, communicate to the public by telecommunication or on the Internet, loan, distribute and sell theses worldwide, for commercial or noncommercial purposes, in microform, paper, electronic and/or any other formats.

The author retains copyright ownership and moral rights in this thesis. Neither the thesis nor substantial extracts from it may be printed or otherwise reproduced without the author's permission.
AVIS:

L'auteur a accordé une licence non exclusive permettant à la Bibliothèque et Archives Canada de reproduire, publier, archiver, sauvegarder, conserver, transmettre au public par télécommunication ou par l'Internet, prêter, distribuer et vendre des thèses partout dans le monde, à des fins commerciales ou autres, sur support microforme, papier, électronique et/ou autres formats.

L'auteur conserve la propriété du droit d'auteur et des droits moraux qui protège cette thèse. $\mathrm{Ni}$ la thèse ni des extraits substantiels de celle-ci ne doivent être imprimés ou autrement reproduits sans son autorisation.
In compliance with the Canadian Privacy Act some supporting forms may have been removed from this thesis.

While these forms may be included in the document page count, their removal does not represent any loss of content from the thesis.
Conformément à la loi canadienne sur la protection de la vie privée, quelques formulaires secondaires ont été enlevés de cette thèse.

Bien que ces formulaires aient inclus dans la pagination, il n'y aura aucun contenu manquant. 


\begin{abstract}
:
This thesis examines various ways in which Quentin Tarantino's cinephilia is manifested in the concreteness of artistic technique. Working with the films Jackie Brown (1997), Kill Bill Vol. 1 and Vol. 2 (2003-2004), and Inglourious Basterds (2009) as case studies, I explore how Tarantino's cinephilia has changed over the course of his filmmaking career, evolving away from the foregrounding of explicit references to specific films and toward a more subliminal mimicry of the visual styles of the filmmakers he admires. My overall aim has been to use stylistic analysis to demonstrate that the concept of cinephilia must be seen as essential to an assessment of this director's work.
\end{abstract}




\section{Acknowledgements:}

I would here like to acknowledge and thank those individuals without whom this thesis would not have been possible. Special thanks go to Dr. Carl Plantinga and Dr. William Romanowski of the Film Studies faculty at Calvin College (Grand Rapids, Michigan) whose guidance, influence, and encouragement initially set me upon the path of academic Film Studies. Likewise, the feedback provided by Dr. Marc Furstenau and Dr. Zuzana Pick of the Film Studies faculty at Carleton University (Ottawa, Ontario) in both coursework and the initial proposal of my thesis topic, cannot go without mention. And I would like to especially thank my thesis supervisor, Dr. Charles O'Brien, also of the Film Studies faculty at Carleton University, for his immeasurable assistance throughout this entire process. Without his steady guidance, valuable advice and keen insights, this project would have failed very nearly as soon as it began. Thank you.

Finally, I would also like to thank my family for all of their support... especially my wife Anna, whose love, patience, and encouragement has kept me going throughout this entire process. 


\section{Table of Contents:}

Title Page $\quad$ i

Abstract $\quad$ ii

Acknowledgements $\quad$ iii

Table of Contents $\quad$ iv

1. Introduction - Love and Cinema 1

On the Historiography of Film Style $\quad 2$

Cinephilia as a Point of Entry $\quad 6$

Contemporary Cinephilia, Film Style and Tarantino 10

2. The Initial Stylistic Manifestation of Love: Jackie Brown (1997) 14

3. Kill Bill (2003-2004) and the Aesthetic of Acquisition 31

4. Inglourious Basterds (2009): The Diegetization of Cinephilia and the Power of 52 the Medium

5. Concluding Remarks - Love, Cinema, and Future Study 74

$\begin{array}{ll}\text { List of Figures and Captions } & 78\end{array}$

$\begin{array}{ll}\text { Bibliography } & 79\end{array}$ 


\section{Introduction - Love and Cinema:}

Despite being a filmmaker of obvious talents, an extraordinary writer and a gifted visual stylist, a distressing amount of the criticism of Quentin Tarantino's films tends to get bogged down in ethical judgements and moralizing. The content of his filmsgraphically violent by North American standards-is controversial and this fact has, unfortunately, occupied a significant proportion of the discourse surrounding his work at the expense of more fruitful lines of inquiry. I place little to no value in the blanket condemnation of his films that has resulted in some circles. Moreover, my view that his films have consistently been anchored by morality and themes of redemption, or have at very least complicated their supposed endorsement of violence and retribution, will be demonstrated in the coming chapters. While, by and large, I will steer clear of questions pertaining to the moral or ethical implications of Tarantino's films, which have already received much attention from critics and which threaten to distract from the questions of cinephilia central to my analysis, I will touch on matters of morality when they intersect with aesthetic issues, as is the case with Inglourious Basterds (Quentin Tarantino, 2009), which I discuss in chapter 4. Ultimately, however, this project will focus on what I consider the most pertinent element of Tarantino's work and of what he brings to it as an auteur: love of the cinema.

Love, to say the least, is a tricky concept for a film critic to work with. Intuitively understood it is nonetheless next to impossible to define with any degree of specificity, or to explain in non-abstract terms. Despite this amorphousness, love nevertheless finds its place, to one degree or another, at or near the heart of most worthwhile endeavours. This certainly has been the case with cinema, as is suggested by the concept of "cinephilia." I 
will consider this concept in detail toward the end of this Introduction. In the meantime I will propose that cinephilia, however defined, is exemplified in the ongoing cinema of Quentin Tarantino, an artist whose love for his medium is an inescapable component of any assessment of his work. A famously ravenous lifelong movie watcher, Tarantino's love of the cinema has manifested itself in his own work, both in terms of content and style. His most recent works have come to be defined by what I will refer to as an aesthetic of acquisition whereby his particular directorial style invokes the styles of the multitudes of past directors from whom he has taken inspiration. Although it would be accurate to observe that essentially all filmmakers—indeed all artists—exist in relation to those who have come before, in the case of Tarantino this relationship takes on another dimension entirely due to the explicitly cinephilic textual and stylistic character of his work. Indeed, Tarantino is unique among contemporary filmmakers in that his films present his loving affection for past works practically in quotation marks, to the point where who he is citing and how becomes as important as what is actually occurring diegetically in his films.

This thesis project seeks to map the terrain of the distinctly cinephilic character of Tarantino's filmmaking, exploring the ways in which this elusive idea of 'love' can come to be concretely manifested on the level of style, and considering what ramifications this may hold for the historiography of film style.

\section{On the Historiography of Film Style:}

From the tableau aesthetics of Tom, Tom, the Piper's Son (1905) to the editing innovations of Birth of a Nation (D.W Griffith, 1915), from the intellectual montage of 
Battleship Potemkin (Sergei Eisenstein, 1925) to the deeply staged, deep focus compositions and lengthy shots of Citizen Kane (Orson Welles, 1941), from the fragmentation, ambiguity and flagrant aesthetic effects of Breathless (Jean-Luc Godard, 1960) to the hyperkinetic cutting and camera movements of Moulin Rouge (Baz Luhrmann, 2001), the history of film style has been lengthy and complicated. Equally complex and nearly as long has been the history of attempts by film critics, scholars and theoreticians to track, categorize and chronicle film-stylistic developments. Indeed, any project which hypothesizes about significant occurrences in the history of film style will inevitably enter into a discourse with an intellectual tradition now nearly a century old out of which it must draw vital concepts and against which it must position and define the originality of its ideas. Since the central concern of this thesis is Tarantino's directorial style as informed by his cinephilic relationship to past filmmakers, a few remarks concerning the project relative to the stylistic historiography tradition are in order.

A useful source for a historiographical overview is David Bordwell's On the History of Film Style, which identifies the dominant schools of thought for the historiography of film style since its beginnings over a hundred years ago. His suggestion is that for approximately the first seventy years of film history, the historiography of film style was conceived of and theorized about as a part of one of three major research projects. The first, he has termed as "the Standard Version of stylistic history," which, in the 1910s and 1920s, "plotted the history of film as a progressive development from simpler to more complex forms"1 and was proposed by early scholars such as Erwin Panofsky, Iris Barry, Robert Brasillach and Maurice Bardeche; the second,

\footnotetext{
${ }^{1}$ Bordwell, David. On The History of Film Style. Cambridge, Massachusetts: Harvard University Press, 1997: 9.
} 
the Dialectical program, was headed by Andre Bazin who sought to "distinguish, in the cinema between 1920 and 1940, between two broad and opposing trends: those directors who put their faith in the image and those who put their faith in reality", and who championed realist cinema; and the third, headed by Noel Burch whose work "from the 1950 s to the early 1990 s" focused on "the duality between the avant-garde and the mainstream narrative, ${ }^{3}$ was the Oppositional program. While these programs are rarely cited by historians today as inspirations, they remain a looming and influential presence within the field, where they continue to exercise a powerful subliminal impact. Moreover, each contains certain elements which the current project on Tarantino will adopt, and others that it will reject.

For each of these projects, the conception of the 'essence' of cinema has been a cornerstone. For the Standard Version historians, this essence was that which made the cinematic art form distinct from other arts and which distanced it from the medium's capacity for mechanically reproducing reality. By contrast, for Bazin's Dialectical Version this essence was instead that very capacity for reproducing reality that the Standard Version historians rejected. And finally, for Burch the essence was defined by an avant-garde, standing in opposition to the institutional mainstream. However, since the 1980 s if not before, a certain consensus has been reached that there is no universal 'essence' of the medium and that an accounting of style for the entirety of film history is too ambitious a task for any one scholar. Instead, most contemporary style scholars are engaged in what Bordwell calls "piecemeal history", a development he summarizes as follows: "In the 1970s younger historians began to doubt that one scholar could write a

\footnotetext{
${ }^{2}$ Bazin, Andre. What Is Cinema? Berkley: University of California Press, 1967: 24.

${ }^{3}$ Bordwell 84.
} 
comprehensive history of style across the world. By concentrating more narrowly on a period, a line of development, or a single stylistic issue, they avoided the peaks-andvalleys overview and began to study continuity and change on a more minute scale."4 The modesty espoused by this philosophy is important as well to this thesis project on Quentin Tarantino's practice of self-conscious stylistic appropriation, for which this survey of stylistic history will serve as an introduction.

Also essential to this research project is the "auteur" concept which originated in the Dialectical program. One of Bazin's contemporaries, Alexandre Astruc, famously wrote, "I would like to call this new age of cinema the age of camera-stylo (camerapen)." 5 Though this idea had certainly been implicit in the writings of many of the Standard Version historians, it was at this time that the director was most forcefully posited as the primary artistic force behind a film. Indeed, the seeds of what would become auteur theory were sown by the critics writing for Cahiers du Cinema. As my own project concerns Quentin Tarantino's uniquely cinephilic idiosyncrasies and how these have manifested in films via the self-conscious adoption of stylistic tropes made famous in other works, I assume that Tarantino, as the director, is responsible for the stylistic choices that go into the construction of his films. Likewise, it is not from some amorphous library of stylistic options that this project assumes Tarantino has drawn inspiration, but rather from specific films, by specific directors, who will themselves be treated by this project also as the auteurs of their films.

Finally, as an endeavour into piecemeal history, this project requires a point of entry into the broader, century old historiography of film style. The suggestion here will

\footnotetext{
${ }^{4}$ Bordwell 118.

${ }^{5}$ Astruc, Alexandre. "The Birth of a New Avant-Garde: La Camera Stylo." The New Wave. London: Secker \& Warburg, 1968: 32.
} 
be that any study which relates the films of Quentin Tarantino to the broader historiography of film style cannot do so without acknowledging, and indeed placing great focus upon the fact that his directorial style is so distinctly flavoured by his famous love of the cinema. Indeed, the suggestion here is that the most useful point of entry into a study of Tarantino that has, at least in part, a stylistic focus, will be to situate him and his films at the intersection between the academic discourses associated with the historiography of film style and those associated with cinephilia.

\section{Cinephilia as a Point of Entry:}

In 1996, Susan Sontag famously wrote her provocative New York Times article "The Decay of Cinema," mournfully declaring "the ignominious, irreversible decline" of the cinema. She went on to qualify this statement, suggesting that "perhaps it is not cinema that has ended but only cinephilia—the name of the very specific kind of love cinema inspired." ${ }^{6}$ Her pessimistic sentiment was soon echoed by journalists such as Stanley Kauffman ${ }^{7}$ and David Denby, ${ }^{8}$ who lent their voices to the chorus of cries claiming that cinephilia was, in fact, dead.

But to what were these individuals and others like them referring? In Sontag's own words the heart of cinephilia can be located "in the mid-1950s" when "a dazzling number of original, passionate films of the highest seriousness got made" and "thinking about movies, talking about movies became a passion among university students and

\footnotetext{
${ }^{6}$ Sontag, Susan. "The Decay of Cinema." New York Times, 25 February 1996, late final edition: section 6, p. 60.

${ }^{7}$ Kauffmann, Stanley. "A Lost Love?" The New Republic, 9 August 1997.

${ }^{8}$ Denby, David. "The Moviegoers." The New Yorker, 6 April 1998, pp. 94-101.
} 
other young people." Marjike de Valck and Malte Hagener clarify this argument, identifying Sontag's cinephilia as that which was "initiated in the 1950s" and "came to full bloom in the 1960s thanks to the success of the Nouvelle Vague in France and abroad, but also the lively debates in the film magazines Positif, Cahiers de Cinema and the discussions of cinephiles congregating around the Cinema MacMahon and other Parisian movie houses." ${ }^{10}$ For Sontag and those of her ilk, therefore, cinephilia is situated in a very specific time and place, and as Jenna Ng comments, "Inherent in the pursuit of such an affectedly idealized historicity is the inevitable nostalgia, the 'theydon't-make-it-like-they-used-to' sentiment."11

Sontag's funereal views on cinephilia have of late been opposed from many quarters. Included among these are Jenna $\mathrm{Ng}$ who argues that "the pursuit of cinephilia as an undertaking of specific memory overlooks the sheer love that is its core to begin with,"12 as well as de Valck and Hagener who suggest that "since the 1980s, cinephilia has transformed itself" such that it is now "practiced by a new generation of equally devoted cinephiles who display and develop new modes of engagement with the overabundance of cinematic material widely available through advanced technology."13 Perhaps most telling is the statement by Manohla Dargis, who would write in the New York Times eight years later that, "Sontag was mourning a lost world, a world in which movies mattered more than their box office and it seemed as if there were an art cinema on every corner of Manhattan, but she didn't realize a new world of cinephilia was

\footnotetext{
${ }^{9}$ Sontag 60 .

${ }^{10}$ Valck, Marjike de and Malte Hagener. "Down with Cinephilia? Long Live Cinephilia? And Other Videosyncratic pleasures." Cinephilia: Movies, Love and Memory. Amsterdam University Press, Amsterdam, 2005: 11.

" $\mathrm{Ng}$, Jenna. "Love in the Time of Transcultural Fusion: Cinephilia, Homage and Kill Bill." Cinephilia: Movies, Love and Memory. Amsterdam University Press, Amsterdam, 2005: 66.

${ }^{12} \mathrm{Ng} 66$.

${ }^{13}$ de Valck and Hagener 12-13.
} 
coming into being." ${ }^{14}$ While Sontag subscribed to a very specific kind of cinephilia, a love for $a$ cinema, and while that cinephilia may have passed, as Jenna $\mathrm{Ng}$ states, "Cinephilia does not die; it merely takes a different form. Love is ahistorical." 15

Beyond the obvious, self-explanatory love of cinema implied by its name, what then can be understood as being at the heart of cinephilia and how can this concept be utilized as a point of entry for Quentin Tarantino's place in the historiography of film style? Christian Keathley has written extensively on cinephilia and one of the concepts at the heart of his work is that of the cinephiliac moment, a concept which finds its roots in a published dialogue between Noel King and Paul Willemen. Willemen suggests that cinephilia tends to "designate something which resists, which escapes existing networks of critical discourse and theoretical frameworks" ${ }^{\prime 16}$ and further argues that this persistent element, this resistance, this "only trace of the Real in this discourse of cinephilia has something to do with what you perceive to be the privileged, pleasure-giving, fascinating moment of a relationship to what's happening on a screen."17 Keathley extrapolates from this suggestion his conception of the cinephiliac moment, moments of intense pleasure experienced by cinephiles when watching films. Of them he writes, "Whether it is the gesture of a hand, the odd rhythm of a horse's gait, or the sudden change of expression on a face, these moments are experienced by the viewer who encounters them as nothing less than a revelation."18

\footnotetext{
${ }^{14}$ Dargis, Manohla. "The $21^{\text {st }}$ Century Cinephile." New York Times, 14 November 2004, late final edition: section 6, p. 39.

${ }^{15} \mathrm{Ng} 67$.

${ }^{16}$ Willemen, Paul. "Through the Glass Darkly: Cinephilia Reconsidered." Looks and Frictions: Essays in Cultural Studies and Film Theory. Indiana University Press, Bloomington and Indianapolis, 1994: 231.

${ }^{17}$ Willemen 232.

${ }^{18}$ Keathley, Christian. "The Cinephiliac Moment." Framework, 42 (summer 2000)

$<$ http://www.frameworkonline.com/Issue42/42ck.html> (visited 26 Aug. 2010).
} 
It is not precisely Keathley's conception of the cinephiliac moment, those that "achieve this level of memorability—especially if only subjectively—even though they are not designed to," ${ }^{19}$ that will be employed in this project. Rather the focus will be on moments that could be considered cousins to those, moments which Keathley characterizes as being "precisely designed to be memorable." 20 The privileging of the designed elements of the film seems a more natural match for Tarantino's cinephilia, but like Keathley's cinephiliac moment, this designed cinephiliac moment is also revealed through another of Keathley's central concepts, the divided viewership required for panoramic perception.

Both Keathley's cinephiliac moments and the here-proposed designed cinephiliac moments are dependent on what Keathley describes as "an alternative spectatorial practice, one that stands in some contrast to the spectatorial posture assumed by dominant cinema." 21 He explains that, "the cinephile is, on the one hand, focused in the way that the film's makers would want him or her to be. But as the most 'literate' of film viewers, able to 'read' what's on offer with comparatively little effort, the cinephile has a certain amount of perceptual energy left over."22 For Keathley's purposes, the cinephile directs this excess perceptual energy towards a panoramic scanning of the image-analogous to Wolfgang Schivelbusch's description in The Railway Journey of the experience of observing the countryside out of train windows ${ }^{23}$-in search of cinephiliac moments. For my purposes, this concept of the cinephilic divided viewing experience will be adopted

\footnotetext{
${ }^{19}$ Keathley, Christian. "The Cinephiliac Moment and Panoramic Perception." Cinephilia and History, or the Wind in the Trees. Indiana University Press, Bloomington and Indianapolis, 2006: 33.

${ }^{20}$ Keathley "The Cinephiliac Moment and Panoramic Perception" 33.

${ }^{21}$ Keathley "The Cinephiliac Moment and Panoramic Perception" 41.

${ }^{22}$ Keathley "The Cinephiliac Moment."

${ }^{23}$ Schivelbusch, Wolfgang. The Railway Journey. University of California Press, Berkeley, 1986.
} 
here and expanded upon. My assertion is that the cinephilic filmgoer will not only-as Keathley suggests-engage in a panoramic scanning of the image in search of these cinephiliac moments, but will also be engaged in an active practice of recognizing and identifying the specific techniques implemented by the filmmaker. This is precisely the sort of cinephilic engagement Tarantino would appear to have had.

\section{Contemporary Cinephilia, Film Style and Tarantino:}

Orson Welles is said to have watched Stagecoach (John Ford, 1939) 40 times in preparation for the making of Citizen Kane and he is indeed quoted as saying, "After dinner every night for about a month, I'd run Stagecoach.... It was like going to school."24 Jean-Luc Godard has famously peppered his works with numerous references to other films. Martin Scorsese has said that as a result of a lifetime of loving and watching films "what happens is that you find, through these images, a way of writing with the camera that stays in your mind." He argues that this is "not necessarily stealing" but rather that "each film is interlocked with so many other films. You can't get away. Whatever you do now that you think is new was already done in 1913.,25 It is clear that the idea of a filmmaker's cinephilic engagement with previous works informing the style and content of their films neither begins nor ends with Quentin Tarantino. However, he does seem to be something of a special case.

His story, that of a "California-reared, self-proclaimed 'film geek' with five intense years behind the counter at Manhattan Beach's Video Archives, where he devoured countless movies, talked endlessly about them, and developed a game plan

\footnotetext{
${ }^{24}$ Welles, Orson and Bogdanovich, Peter. This is Orson Welles. Da Capo Press, New York, 1998: 28-29.

${ }^{25}$ Ebert, Roger. "Scorsese Learns from Those Who Went before Him." Scorsese by Ebert. The University of Chicago Press, Chicago, 2008: 219.
} 
about making them himself," ${ }^{26}$ has been widely told and his encyclopaedic knowledge of and passion for film has become the stuff of legend. Jenna Ng suggests that Tarantino's movie love is a form of "contemporary cinephilia," the "unique thrust" of which "is its fluency of transcultural film literacy, one manifestation of which lies in today's plethora of cross-cultural filmic intertextuality, born from a diversity of film culture experiences afforded primarily by home video, cable network and most recently the internet and DVD."27 Like Scorsese, Tarantino's cinephilia has caused him to find ways of writing with the camera. In his case, however, this has become more explicit, taking the form of "the cinephilic impulse of intertextual referencing: love shown in tribute and celebration inherent in the practices of homage and memorialisation, conveying an uncanny mixture of admiration and affection., 28

A final point must be made here regarding this form of cinephilic filmmaking and the manner in which the relationship between the filmmaker and the films he references is sometimes dismissively discussed in terms of influence. The implicit suggestion is that the current filmmaker's work is subordinate to the films that 'influence' him, as if such films exhibit agency over him. In his book Patterns of Intention, Michael Baxandall disputes this mentality, arguing that, “'Influence' is a curse of art criticism primarily because of its wrong-headed grammatical prejudice about who is the agent and who the patient: it seems to reverse the active/passive relation which the historical actor experiences and the inferential beholder will wish to take into account." ${ }^{29}$ Indeed, as Baxandall argues, and as my own work will go on to demonstrate with regard to

\footnotetext{
${ }^{26}$ Peary, Gerald Quentın Tarantıno: Intervıews. Unıversıty Press of Missıssıppı, Jackson, 1998. VII

${ }^{27} \mathrm{Ng} 67$

${ }^{28} \mathrm{Ng} 69$.

${ }^{29}$ Baxandall, Michael. "Excursus Against Influence." Patterns of Intention: On the Historical Explanation of Pictures New Haven' Yale Unıversity Press, 1985 58-59
} 
Tarantino's filmmaking, "If one says $\mathrm{X}$ influenced $\mathrm{Y}$ it does seem that one is saying that $\mathrm{X}$ did something to $\mathrm{Y}$ rather than that $\mathrm{Y}$ did something to $\mathrm{X}$. But in the consideration of good pictures and painters" or indeed filmmakers "the second is always the more lively reality. ${ }^{30}$ Indeed, it should therefore be pointed out that this project will make no mention about how certain films or filmmakers have 'influenced' Quentin Tarantino. Instead, the focus shall be upon how Quentin Tarantino's love for the medium manifests in references, invocations, and appropriations of elements of past works, and to what effects this act of agency on his part is directed.

This project aims to engage with this new breed of cinephilic filmmaking and in the following chapters will endeavour to situate it within the broader historiography of film style. It is an interesting reality that most published works on Quentin Tarantino end where this project will begin, with Jackie Brown (Tarantino, 1997). While Reservoir Dogs (Tarantino, 1992) and Pulp Fiction (Tarantino, 1994) have been widely written on, the latter portion of the director's career has received comparatively little attention. Ironically, as this study will demonstrate, it is not until Jackie Brown that the most interesting manifestations of Tarantino's cinephilia first begin to emerge. Indeed, the second chapter will analyze Jackie Brown, indicating the ways in which it represents a significant development in the role of Tarantino's cinephilia in his filmmaking, namely, the first prominent example of its manifestation on the level of style. The third chapter will then be an analysis of Kill Bill vol. 1 and 2 (Tarantino, 2003-2004) which will engage with the extensive and explicit intertextual referencing present therein and suggest that it is with this work that Tarantino's aesthetic of acquisition officially takes form. The fourth chapter will, in turn, analyse Inglourious Basterds in the light of the

\footnotetext{
${ }^{30}$ Baxandall 59 .
} 
cinephilic aesthetic which has emerged over the previous films, engage with the unprecedented diegetization of the director's cinephilia that is there on display, and explore the manner in which the film takes as its subject the power of the cinema itself. Finally, the project will conclude with a chapter which will summarize the findings of the aforementioned three and will further argue for the viability of continued work in film studies from the perspective of situating the elusive concept of love in more concrete terms within the broader field of film style historiography. 


\section{Chapter Two: The Initial Stylistic Manifestation of Love: Jackie Brown (1997)}

In assessing how Tarantino's cinephilia manifests itself in his films, consider the following examples. Clarence Worley (Christian Slater), the protagonist of True Romance (Tony Scott, 1993), meets Alabama Whitman (Patricia Arquette), the girl he falls in love with, at a Sonny Chiba triple feature of The Street Fighter (Shigehiro Ozawa, 1974), Return of the Street Fighter (Ozawa, 1974), and Sister Street Fighter (Kazuhiko Yamaguchi, 1974). Their adventures take them to Los Angeles where they enter into an illicit drug transaction with Lee Donowitz (Saul Rubinek) a Hollywood producer with whom the film geek Clarence-purportedly partially based on Tarantino who penned the script —enters into a conversation about the dailies of Donowitz's new film, along with the "safe, geriatric, coffee table dogshit" that usually wins Oscars, and "movies with balls" ${ }^{31}$ like Mad Max (George Miller, 1979), The Good, the Bad, and the Ugly (Sergio Leone, 1966), Rio Bravo (Howard Hawks, 1959), and The Deer Hunter (Michael Cimino, 1978). In Reservoir Dogs, Freddy's (Tim Roth) superior officer in the police department Holdaway (Randy Brooks) states that "undercover cops gotta be Marlon Brando",32, and once undercover as Mr. Orange, Freddy converses with Misters White, Pink and 'Nice Guy’ Eddie about Get Christie Love (1974-1975), which he describes as "a Pam Grier TV show without Pam Grier." ${ }^{, 3}$ In Pulp Fiction, Jules Winfield (Samuel L. Jackson) discusses television pilots with Vincent Vega (John Travolta) who later takes Mia Wallace (Uma Thurman) out to dinner at Jack Rabbit Slim's, a themed diner where the wait staff is comprised of lookalikes of Hollywood stars of the 1950s such as Marilyn

\footnotetext{
${ }^{31}$ Scott, Tony. True Romance. Morgan Creek Productions, 1993.

32 Tarantino, Quentin. Reservoir Dogs. Live Entertainment, 1992.

33 Tarantino, Quentin. Reservoir Dogs. Live Entertainment, 1992.
} 
Monroe and Mamie Van Doren. The film also contains a winking reference to the classic film noir Kiss Me Deadly (Robert Aldrich, 1955) in the form of the briefcase with unidentified shining contents.

The examples listed above all demonstrate not only that Tarantino's films have, from the very start, been informed by his cinephilia but that the cinephilia evident in his early work tends to feature two attributes. First, it is largely displayed through diegetic textual references; and second, these cinephilic displays are largely subsumed by Tarantino's broader affection for popular culture. In True Romance, Clarence is as enamoured of Elvis Presley as he is of the cinema, Reservoir Dogs characters are just as likely to be found discussing the hidden meaning of Madonna lyrics as anything to do with movies, and in Pulp Fiction Jules and Vincent's discussion of television pilots is preceded by a conversation about McDonalds and the fact that in Paris the Quarter Pounder with cheese is known as the Royale with cheese.

A change in the nature of Tarantino's cinephilia occurs, however, with the director's third feature Jackie Brown which begins a tendency in his subsequent films of foregrounding his love for the cinema in a more concrete and interesting manner. That is to say, by Jackie Brown Tarantino's cinephilia begins to manifest itself not only via explicit references to specific favourite films but stylistically in the film's images and soundtrack. It is hardly the case that Tarantino in Jackie Brown eschews entirely his penchant for peppering his films with textual references to other films. Quite to the contrary, when speaking to his prospective partner in crime Louis Gara (Robert De Niro) the arms dealer Ordell Robbie (Samuel L. Jackson) complains that many of his clients derive their taste in weaponry from the movies they watch, such as The Killer (John Woo, 
1989), rather than from any of the actual attributes of the guns in question. Additionally, one of Ordell's live-in girlfriends Melanie Ralston (Bridget Fonda) spends most of her time watching movies on television such as Beast With a Gun (Sergio Grieco, 1977) which prompts a discussion with Ordell as to whether the male lead is Rutger Hauer or Helmut Berger, and Crazy Mary, Dirty Larry (John Hough, 1974) which, in another winking reference on Tarantino's part, stars Peter Fonda, Bridget's father. These trademark references notwithstanding, however, Jackie Brown also foregrounds the director's love for his medium in a deeper, richer manner on the level of style.

Jackie Brown is an adaptation of the novel Rum Punch (Elmore Leonard, 1992) and, indeed, has been described by Leonard as "the truest adaptation of any of my books to reach the screen." ${ }^{34}$ Its faithfulness to the source material aside, it is nevertheless precisely in the ways by which Tarantino's film deviates from Leonard's novel that the director's cinephilia is brought to the fore. The manner in which Tarantino subtly reshaped the narrative is telling and this selective stripping away of several of the novel's subplots is outlined by Edward Gallafent who writes, "What Tarantino wants to extract from Rum Punch is indicated by his change of title. Jackie Brown becomes Jackie's story." 35 Indeed, what was arguably merely one of several central characters in Leonard's novel is recast as the undisputable central role of Tarantino's film. Even more significant, however, is Tarantino's choice to convert Jackie Burke-the blonde haired Caucasian character from Leonard's text-- to Jackie Brown, an African American woman whose name is an amalgamation of Leonard's "Jackie Burke" and the titular character from the blaxploitation film Foxy Brown (Jack Hill, 1974) who was famously played by

\footnotetext{
${ }^{34}$ Leonard, Elmore. "A Letter From Elmore Leonard." Jackie Brown Collector's Edition Booklet. Alliance Atlantis Communications Inc., Canada, 2002: 4.

${ }^{35}$ Gallafent, Edward. Quentin Tarantino. Harlow, England: Pearson Education Limited, 2006: 89.
} 
Pam Grier who here portrays Jackie Brown. This casting choice and the approach Tarantino adopts to her audiovisual presentation on the screen is one of the primary loci of the film's cinephilically informed film style. Indeed, it is through a combination of the 1970s soul music which constitutes a majority of the soundtrack, and the deliberately iconographic depiction of Pam Grier's image in the film's cinematography, that Tarantino's affection for cinema, specifically of the blaxploitation variety, manifests itself on the level of style in Jackie Brown.

The film's opening credit sequence which, as Edward Gallafent points out, "has no equivalent in Rum Punch, ${ }^{36}$ immediately establishes an affectionate relationship between Jackie Brown and the blaxploitation films of the 1970s. Described by the director himself as "the greatest Pam Grier opening sequence of all time" ${ }^{\text {"37 }}$ the sequence is six minutes and twenty-five seconds in duration and set to the music of Bobby Womack's 1973 soul song “Across $110^{\text {th }}$ Street”. As Robert Miklitsch indicates, "The music-induced mood" of this sequence "is wonderfully expressive, recollecting as it does Across 110th Street (Barry Shear, 1972), a film that is contemporaneous with Shaft (Gordon Parks, 1971) and for which Womack wrote the title song and score." ${ }^{38}$ Indeed, musically Tarantino invokes blaxploitation cinema throughout Jackie Brown, implicitly through his usage of 1970 s soul songs such as the aforementioned "Across $110^{\text {th }}$ Street" as well as "Strawberry Letter 23" (The Brothers Johnson, 1977), "Natural High" (Bloodstone, 1973), “Didn’t I (Blow Your Mind This Time)" (The Delfonics, 1970) and "Street Life" (Randy Crawford, 1979), and more explicitly through "Long Time Woman"

\footnotetext{
${ }^{36}$ Gallafent 89.

${ }^{37}$ Tarantino, Quentin. Interview with Adrian Wooten. The Guardian. 5 Jan. 1998, 23 Oct. 2010 <http://www.guardian.co.uk/film/1998/jan/05/quentintarantino.guardianinterviewsatbfisouthbank1>.

${ }^{38}$ Miklitsch, Robert. "Audiophilia: Audiovisual Pleasure and Narrative Cinema in Jackie Brown." Screen. Winter 2004, Vol. 45 Issue 4: 290-291.
} 
(Pam Grier, 1971) which Grier initially recorded for the blaxploitation film The Big Doll House (Jack Hill, 1971), and selections from Roy Ayer's original score for the blaxploitation classic Coffy (Jack Hill, 1973) which also starred Pam Grier. Throughout Jackie Brown the music consistently "invokes that larger cinematic 'structure of feeling', blaxploitation, which remains the audiovisual source for the character of Jackie Brown." 39 Ultimately, however, the music plays a supporting role in the stylistic evocation of blaxploitation cinema, secondary to the visual presentation of Pam Grier.

"Across $110^{\text {th }}$ Street" begins to play before the film truly commences, first playing over the initial "Miramax Films" and "A Band Apart" graphics identifying the studio and Tarantino's production company respectively. The opening shot of the film fades in on a blue tiled surface which we will later learn is a wall at the Los Angeles International Airport, but that first serves as a stationary backdrop for the opening credits which take approximately twenty seconds to again acknowledge Miramax and A Band Apart before displaying the director's signature "A Film by Quentin Tarantino." Then, immediately after the signature fades and precisely when the actual lyrics of the song begin, Pam Grier glides into view in profile on what we soon realize is a moving sidewalk and the camera begins to track alongside her progress in a medium shot for a further two minutes while the credits continue to roll. It is a striking image, one which Kent Jones describes as "a state of rapturous absorption" 40 on the part of Tarantino's camera and, indeed, one that will be returned to in various iterations repeatedly throughout the film.

\footnotetext{
${ }^{39}$ Miklitsch 291.

${ }^{40}$ Jones, Kent. "Critic's Heart is an Ocean of Longing: Après-Christmas Grumblings." Film Comment. Mar/Apr 1998; Vol. 34, No. 2: 24.
} 


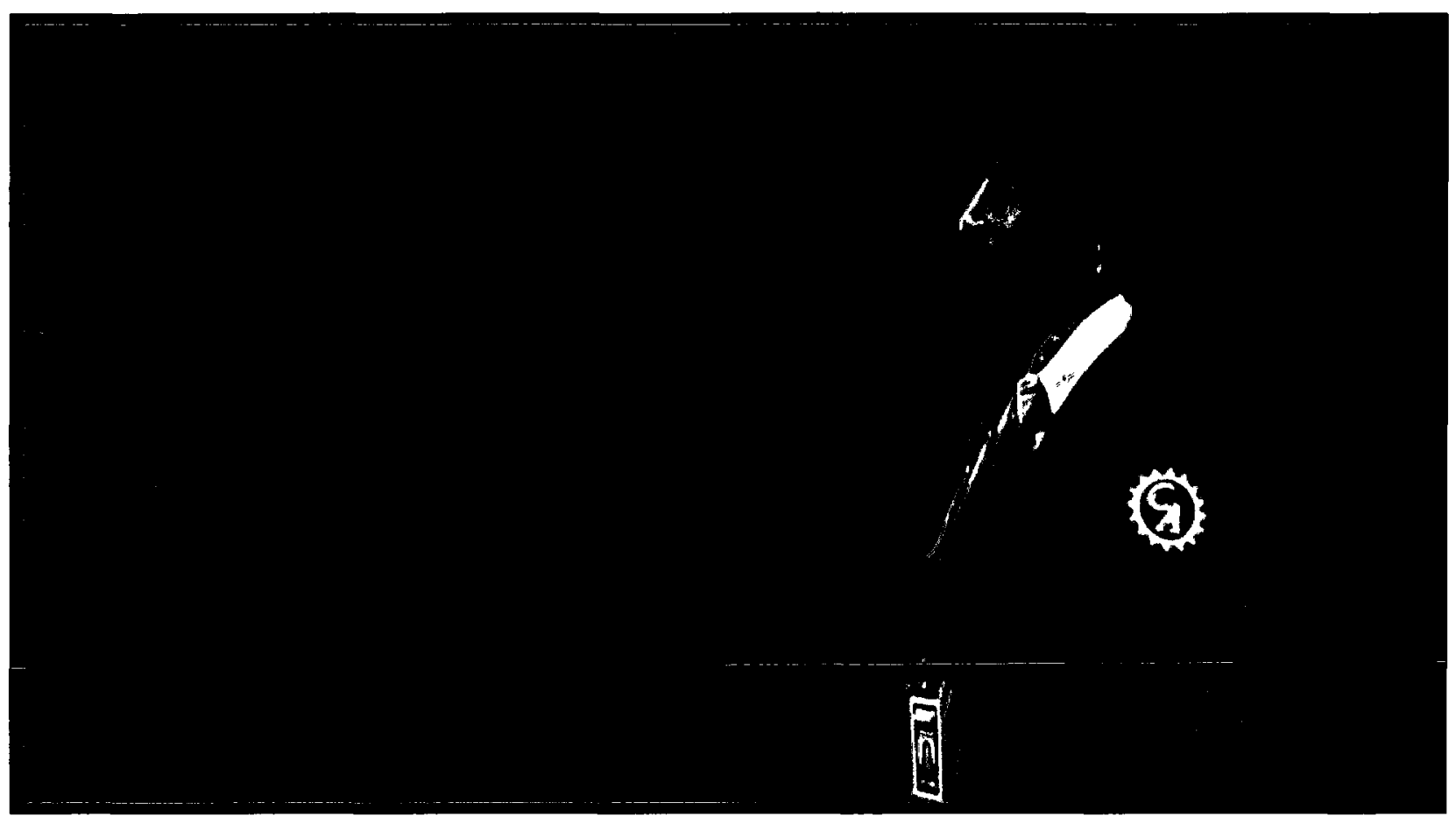

Fig. 2.1: The opening shot of Jackie Brown is a 2 minute tracking shot of Pam Grier gliding along on a moving sidewalk at LAX.

As Antoine de Baecque writes, "In all the shots where Pam Grier appears, Tarantino's camera, seemingly mesmerized by her presence, aligns itself on her majestic profile or freezes to watch her approach, and her every move to the point that each of her movements, each word she utters with such precise diction overwhelms everything else in the end." ${ }^{41}$ Indeed, after a brief sequence verifying our location as an airport and depicting airport procedures, there is a twenty second tracking shot, again in profile but now wider so as to capture Grier's entire figure as well as some of her immediate surroundings, taken from a low angle of her walking, followed by a low angle medium shot frontal view of the same action continuing for fifteen seconds, and an additional fifteen second close-up of her face once more in profile. It seems an appropriate claim on

\footnotetext{
${ }^{41}$ De Baecque, Antoine. "The Disillusioned Enthusiasm of Quentin Tarantino: A Reflection on Jackie Brown." Jackie Brown: Collector's Edition DVD. Alliance Atlantis Communications Inc., Canada, 2002. Translated and Expanded from "Jackie Brown." Cahiers du Cinema, April 1998, Vol. 523: 26-28.
} 
the part of Kent Jones that 'I've never seen anything quite like Tarantino's treatment of Pam Grier in this movie, which is no mere case of rescuing and propping up a fallen icon." ${ }^{42}$ Indeed, Tarantino does not so much rescue and prop Grier up as put her on display and rejoice in her glory, prompting Antoine de Baecque to make the claim that "Tarantino filmed Grier like a goddess" celebrating her maturity "and her identity as a star who has worked in a genre that has been looked down upon without ever sacrificing her honor or her dignity."

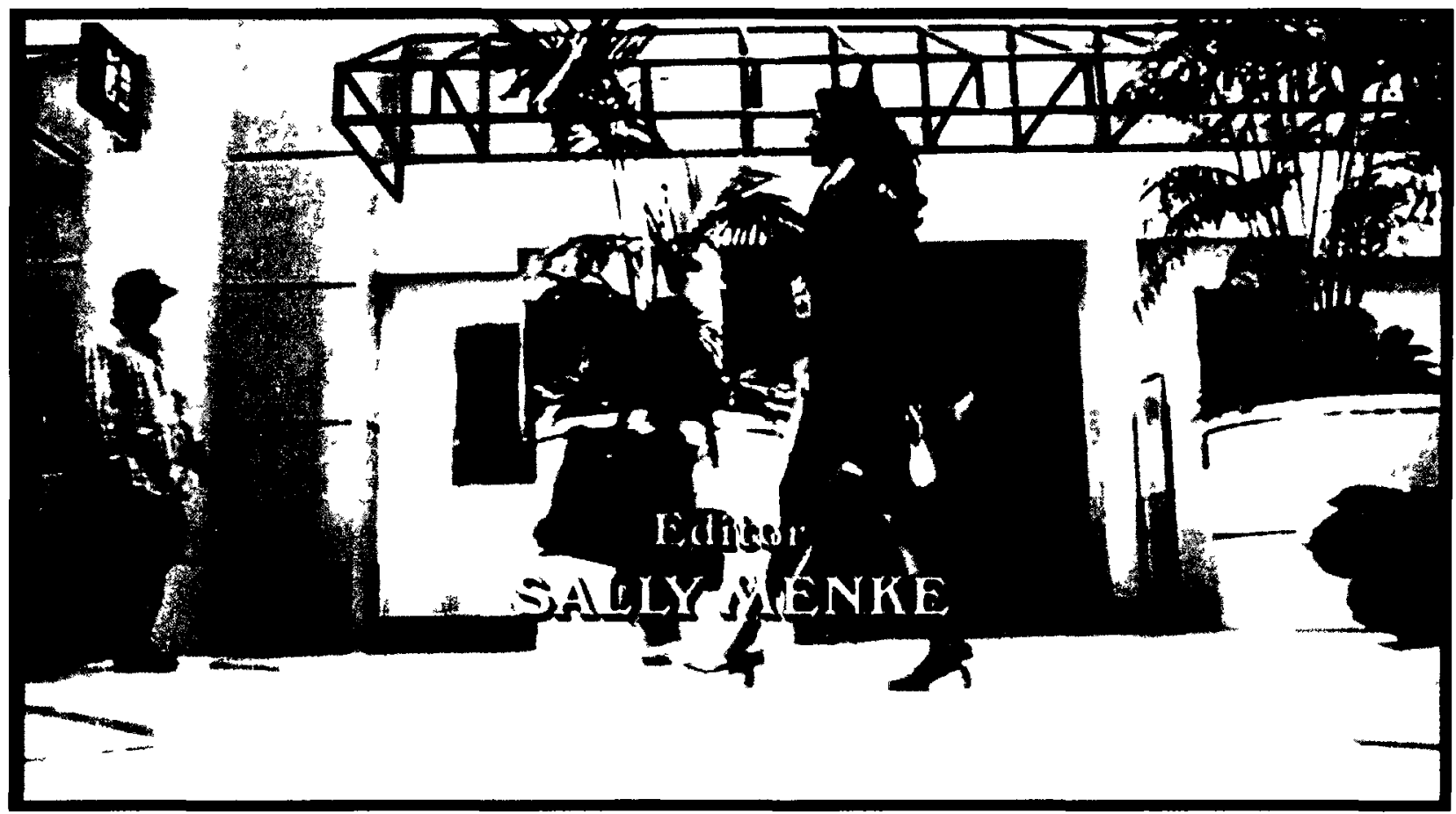

Fig. 2.2: Shot from a low angle so as to maximize her stature and tracked alongside for twenty seconds, this comes as a part of a series of shots which cinephilically put Grier on display.

Of course, Tarantino is hardly one who would feel that genre stars require propping up. An outspoken proponent of practically all types of cinema, including genre fare of the sort that is looked down upon in many circles, one of the cinephilic director's

\footnotetext{
${ }^{42}$ Jones 24.

${ }^{43}$ De Baecque
} 
many loves has been 1970 s exploitation cinema, including the blaxploitation fare in which Grier first made her name. Describing his affection for this subgenre in an interview, Tarantino has said of blaxploitation films:

They had a certain kind of vitality that really only lurid paperbacks had in the way that they dealt with things. There was one more aspect about them that was just wonderfully unique. There was nothing like them before they came out. They were completely, utterly unique in look, in feel - like you said, the sound track - in the complete embracing of black culture. They presented a black world in a way that had not been seen before, except if you look at the old coloured movies where Lionel Jeffreys is the cowboy walking around. They presented a black world. They were going to say it out loud: "I am black and I am proud" kind of world. There was nothing like them before. When they left, there was nothing to take their place. They really left a void. ${ }^{44}$

This affection for a largely disrespected type of film is embodied in the director's stylistic treatment of Grier in Jackie Brown. Kent Jones has made mention of “Grier's Roman profile" ${ }^{, 45}$ in the film, and indeed the many extended profile shots of Grier do bear more than a passing resemblance to a bronze bust or the image of a Caesar imprinted on a coin, a commemorative representation of a worthy personage.

${ }^{44}$ Tarantino Interview. The Guardian.

45 Jones 24. 


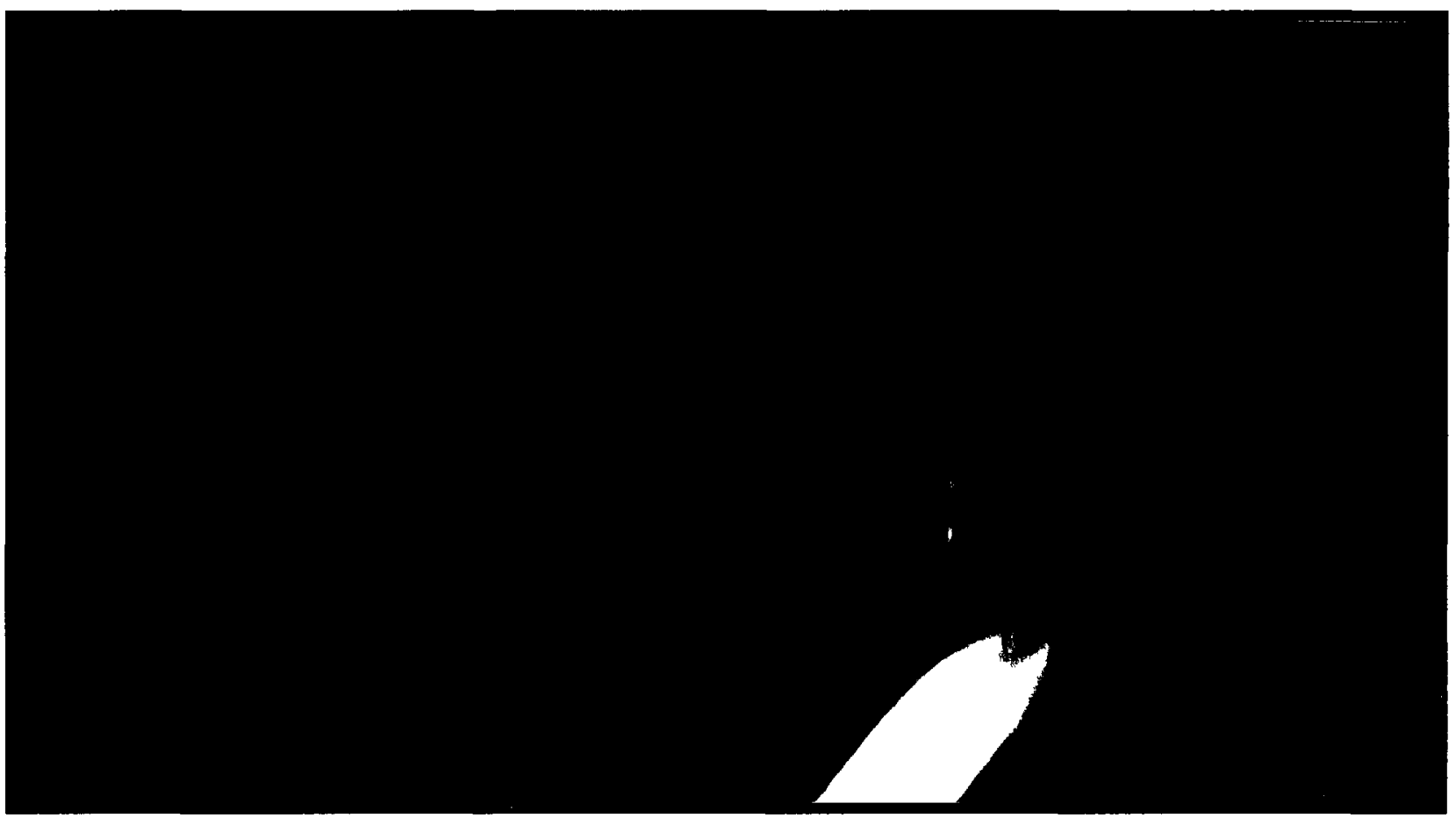

Fig. 2.3: The profile framing of Grier in this 15 second close-up (as elsewhere) is reminiscent of an image on a coin or a bust and has the effect of presenting her image has a tribute to both her history in blaxploitation films and to the subgenre itself.

As such objects paid tribute to the great people in question so too does Tarantino, in all of the extended shots of Grier, but especially the ones taken in profile, present the image of the actress as tribute to all of the famous blaxploitation roles she played and by extension to the blaxploitation cinema itself which he here celebrates.

It is perhaps here significant to point out the difference between the allusions and homage to the subgenre that Tarantino is engaged in here, and the imitative duplication that he is not. He has not, with Jackie Brown, made a blaxploitation film of his own and has indicated as much in interviews, insisting to The Guardian that Jackie Brown "is not a black exploitation film" 46 and informing Michel Ciment and Hubert Niogret of the film journal Positif that "I didn't want to do a parody of a Blaxploitation movie, especially

\footnotetext{
${ }^{46}$ Tarantino Interview. The Guardian.
} 
since the action doesn't even take place in the '70s." ${ }^{47}$ And indeed, a cursory investigation of the films themselves would seem to verify the director's claims.

The two blaxploitation films most frequently cited as an influence on Tarantino, particularly in regard to Jackie Brown, are Coffy and Foxy Brown, both of which star Pam Grier. The influence of Foxy Brown can be most tangibly demonstrated in the previously mentioned causal relation that exists between the two film titles, and Coffy, of which Tarantino has said, "Coffy is one of my favourite movies, actually; I love Coffy," previously mentioned, is the source of Jackie Brown's musical score. Beyond the obvious affection for such films that is evoked through Jackie Brown's style, however, Tarantino's film bears scant resemblance to them. Both Coffy and Foxy Brown adhere to the same general formula (which cynical viewers could interpret as something akin to 'low production values $+\operatorname{sex}+$ violence $=$ profit' $)$, featuring the titular female protagonist played by Grier opposed to a broad, general idea of drugs conveniently embodied in each film by a few villainous characters against whom Grier eventually takes bloody revenge (a shotgun massacre in Coffy, a castration of the primary drug dealer in Foxy Brown), but not before going undercover in their organizations (each time as a prostitute) and running into trouble along the way. Each film also features a number of blatantly exploitative scenes designed to appeal to the audience's baser interests. Indeed, a particularly outlandish scene in Coffy features a brothel 'girlfight' involving bowls of salad, bottles of wine, strategically placed razorblades in Coffy's afro, and various fighting manoeuvres which conveniently expose the breasts of the combatants.

${ }^{47}$ Tarantino, Quentin. Interview with Michel Ciment and Hubert Niogret. Positif. April, 1998, Vol. 446: 17-22.

${ }^{48}$ Tarantino Interview. The Guardian. 
By any measurement, Jackie Brown is a very different animal. On the surface its pulpy narrative could certainly be misconstrued as the stuff of exploitation what with its depiction of shady criminal dealings, illegal gun merchants, cash smuggling, capers, double and triple crosses, and murder, but Tarantino's treatment of the subject elevates it squarely out of the exploitation realm. Indeed, far from being an exploitation film (black of otherwise), it was roundly labelled, at the time of its release, as Tarantino's most mature film to that point, and in fact, Antoine de Baecque identifies maturity itself as "the true topic of the movie, its constant objective. ${ }^{, 49}$ While gunfire and retribution are unabashedly embraced by films like Coffy and Foxy Brown, de Beacque suggests:

Shots are traded in Jackie Brown, but furtively; guns are drawn, but they're weighted with nostalgia and death; corpses appear, but they lurk, they haunt more than they fall... the bodies are not virtual, the exchanges refuse any choreography, violence runs away from ballet and the space is not an opera or church scene. Time has seized appearances and aged things, while the melancholy has imposed other forms of wrinkles on the places and the actions. Nothing is easy, but all is still; nothing is a breeze, everything moves in slow motion. It's the destiny of the minuscule lives filmed by Quentin Tarantino: they find their greatness in the serenity of the gestures and of the evidence of time passing. Like Pam Grier whispering the words of a song heard on the radio. ${ }^{50}$

Rather than a shallow, revenge driven blaxploitation film then, Jackie Brown is, as Kent Jones has written, “A young man's film about growing old, in which life, usually a backdrop, occupies the centre and dictates the rhythm of attention." ${ }^{, 1}$ While Tarantino celebrates the lurid blaxploitation subgenre through elements of the film's style, he offers up a film of far more subtly and depth.

Anchored by the relationship between Jackie and her bailbondsman Max Cherry (Robert Forster), Jackie Brown is a film that gets "into feelings and sensations of unusual

\footnotetext{
${ }^{49}$ De Baecque.

${ }^{50}$ De Baecque.

${ }^{51}$ Jones 24.
} 
delicacy." 52 Without including any sex scenes, or indeed any of the nudity that runs rampant in blaxploitation films, the heart of Tarantino's film is this sweet, subtle love story between a 44-year-old airline stewardess and a 56-year-old bailbondsman. A love story where a man "for whom every word and move are old and tired and who is well past the age when he thinks he's capable of remaking himself ${ }^{, 53}$ and a middle-aged African American woman who has been forced to come to terms with her limited possibilities for the future, find in one another exactly what is needed to ignite and reenergize their lives. Tarantino himself has indicated that:

Jackie Brown and Max Cherry have something broken in them. Max seems to have been asleep for six or seven years. He doesn't even think that he is disappointed by life because he's too asleep to even notice! It will take the trials faced by Jackie for him to wake up. We don't know what happened to him, maybe a bad divorce. At least, that's what I think. What touches in their relationship, it's that, at first, he's not really in love with her but he desires her and he's probably forgotten how it felt to desire a woman. And there's nothing more wonderful than that sensation: to forget and to rediscover desire. ${ }^{54}$

Real people with depth and nuance, Max and Jackie's relationship is underpinned by the film's musical soundtrack which, in addition to evoking blaxploitation films due to its consisting of 1970s soul songs, also takes on a significant role with regard to these central characters. Kent Jones suggests that "the Seventies tunes are on the soundtrack here for a very particular reason: this is the music of characters who are too old and tired to listen to anything new-this is the music of their youth, which is now over." 55 The Delfonics song "Didn't I (Blow Your Mind This Time)", which Jackie initially plays for Max at her apartment and which he subsequently (after purchasing the cassette) continually listens to

\footnotetext{
${ }^{52}$ Jones 25.

${ }^{53}$ Jones 25.

${ }_{55}^{54}$ Tarantino Interview. Positif. 17-22.

${ }^{55}$ Jones 24.
} 
in his car, in particular comes to represent, generally, the relationship between the two, and specifically, Max Cherry's feelings for Jackie and "the slow sense of surprise that mounts within" him "as he realizes that Jackie has stirred something in him."56

One of the key outcomes of Tarantino's stylistic invocation of blaxploitation cinema within a film that is far from exploitative is that in the process he has provided his blaxploitation icon Grier with a role, that of Jackie Brown, which transcends those of her past. Robert Miklitsch has suggested that Tarantino's “desire to showcase Pam Grier" does not so much present her as "the 'mythical, 'super-bad-momma' that audiences, like Tarantino, tend to associate with her younger, 'badder' self," but rather that he showcases "Pam Grier not as Foxy but Jackie Brown: not some scopic fantasy, a gangsta Lady Godiva 'walking down the street to burn Harlem' to the ground but a 'woman working in this world', a woman with her feet planted firmly on the ground." ${ }^{57}$ This is certainly in keeping with Tarantino's own statements on the subject that Jackie is "not Foxy Brown twenty years later... She's a human being of flesh and blood"58 and this concept of rooting his blaxploitation icon in reality, in humanity, is borne out in some of the same sequences that cinephilically celebrate blaxploitation.

In the previously examined credit sequence, the shot immediately following the fifteen second close-up of Grier in profile, is a wider ten second shot in which all but Grier's feet are in view and in which she can be clearly seen to be picking up speed as she makes her way through the airport. The following shot directly echoes the opening, by again tracking alongside Grier in a medium shot, again for approximately two minutes, and for the majority of the shot again in profile. This time, however, Grier isn't

\footnotetext{
${ }^{56}$ Jones 25.

${ }^{57}$ Miklitsch 304.

${ }^{58}$ Tarantıno Interview Positıf 17-22
} 
gliding along or striding forth with an air of regality, instead at the opening of the shot she is hurriedly walking and seconds later breaks into a jog and by her demeanour it is made clear that she is late for work.

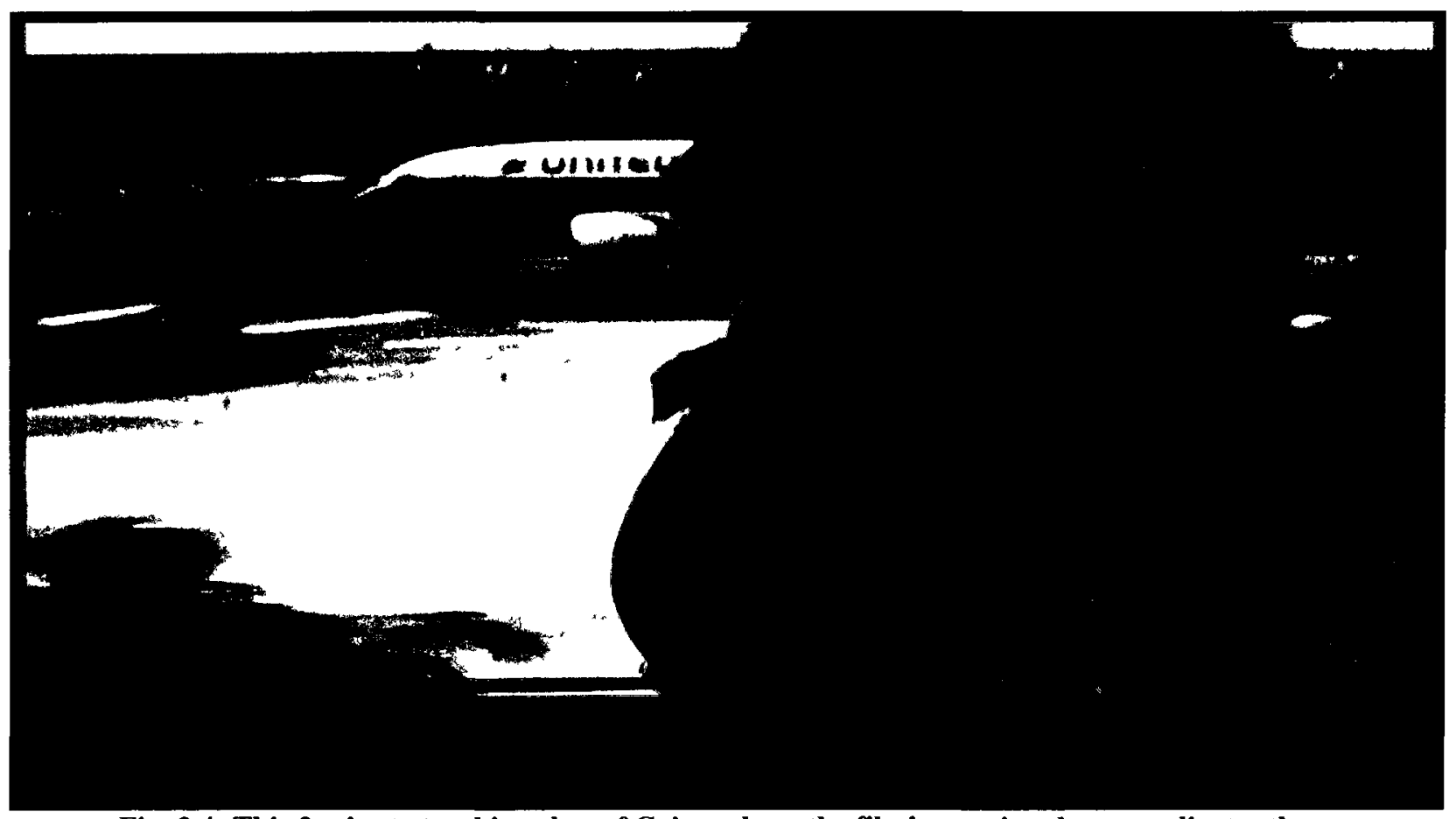

Fig. 2.4: This 2 minute tracking shot of Grier echoes the film's opening, but complicates the iconic celebration of Grier's image by depicting her in a hurried rush to reach work on time.

As Tarantino says:

She is not walking down the street to burn Harlem to the ground. She is a woman working in this world, and she is late for her job, and she is going to get fired if she does not get there. After the big bad ass opening credit sequence, two minutes later she is serving peanuts. So it starts off as this mythical, super hero figure and then by the end of the credit sequence we have brought it back down to earth. ${ }^{59}$

The effect is not one of undermining the cinephilic evocation of the film's opening minutes-indeed I would suggest that Tarantino's camera is every bit as much in love with the 'real' Jackie Brown as it is with the memory of the 'mythic' Coffy or Foxy Brown-rather it is one of firmly grounding the director's obvious affection for his star,

\footnotetext{
${ }^{59}$ Tarantıno Interview. The Guardıan.
} 
and for that which his stylistic depiction of her makes her into an iconic representation, within the greater context of the film as a whole.

This would seem a useful time to return to the insights Michael Baxandall has provided with regards to agency and the influence paradigm. Everything that has been examined here concerning Tarantino's Jackie Brown and its relation to blaxploitation cinema, seems in perfect congruence with Baxandall's view that speaking with regard to influence is a "wrong headed grammatical prejudice about who is the agent and who the patient." ${ }^{60}$ Indeed, one could rephrase Baxandall's statement on Picasso's references in interviews to Cézanne to apply to Tarantino's invocation in interviews of blaxploitation cinema. In Jackie Brown, 'Tarantino acted on blaxploitation cinema quite sharply. For one thing he rewrote film history by making blaxploitation a that much larger and more central historical fact in 1997 than it had been in 1980: he shifted it further into the main tradition of American cinema., ${ }^{61}$ And this would seem to be much the point. Despite the director's own comments regarding the films he loves, Tarantino's work is not subservient to the influence of the blaxploitation films he invokes through his musical selections and his visual depiction of Pam Grier's image. To the contrary, Tarantino's statements suggest a situation in which he rather than blaxploitation cinema is the agent. In other words, Tarantino has opted to make reference to blaxploitation films in order cue critics concerning the appropriate frame for understanding his film and to celebrate these films and share his love for them with his audience.

\footnotetext{
${ }^{60}$ Baxandall, Michael. "Excursus Against Influence." Patterns of Intention: On the Historical Explanation of Pictures. New Haven: Yale University Press, 1985: 58-59.

${ }^{61}$ The original Baxandall quote reads, "Picasso acted on Cézanne quite sharply. For one thing, he rewrote art history by making Cézanne a that much larger and more central historical fact in 1910 than he had been in 1906: he shifted him further into the main tradition of European painting" (61).
} 
While it is certainly here argued that Jackie Brown marks a turning point in Tarantino's oeuvre-it is the film that first prominently manifests the director's cinephilia on the level of style as opposed merely to the level of diegetic text-a final point must be made differentiating the manner in which his love for the medium is manifested stylistically here, from the previously proposed aesthetic of acquisition which will typify his later films. On the one hand, it is true that Tarantino's implementation of 1970s soul music and portions of the musical score for Coffy are consistent both with the concept of an aesthetic of acquisition and with the manner in which Tarantino will go on to employ music in his later films. On the other hand, there is a marked difference between the visual evocation of blaxploitation cinema in Jackie Brown and the specific invocation of the styles of the past directors from whom he has taken inspiration which will characterize his subsequent work.

Located as it is primarily within specific iconographically mounted images of Pam Grier, Tarantino's evocation of blaxploitation cinema is achieved stylistically without necessarily invoking blaxploitation style. In addition to the opening credit sequence, this type of image recurs sporadically throughout the film and it will be useful to here point out its defining attributes. On a basic level, these shots are the result of fastening the camera to Grier, generally while she is in motion, while music plays either diegetically or nondiegetically. While a cinemetric analysis of Jackie Brown reveals that it, in general, features an unusually long average shot length of 7.7 seconds (a high figure in light of Barry Salt's research into recent American cinema), the contrast between shots that contain Grier and shots that do not is striking. ${ }^{62}$ While the shots not containing Grier feature an average shot length of 6.7 seconds, those featuring Grier average a

\footnotetext{
${ }^{62}$ Salt, Barry. Moving Into Pictures: More on Film History, Style, and Analysis. London: Starword, 2006.
} 
significantly longer 9.8 seconds. Indeed, as the previous examination of the opening credit sequence has revealed, the iconographic Pam Grier shots set to music are significantly longer still. Indeed, other chief examples include a 10 second medium close-up shot of Grier in profile set to the music of Randy Crawford's "Steet Life" and shot against a blue tiled background (clearly evoking the film's opening shot) immediately before the Del Almo Mall caper which ultimately nets her $\$ 500,000$, as well as a sequence of two steadicam tracking shots immediately after the caper, set to the track "Escape" from the Coffy soundtrack, 49 and 87 seconds in duration respectively, also predominantly in medium close-up, but circling her to provide a panorama of views. Shots like these, or indeed, the 73 second closing shot of the film which is a frontal closeup of Grier set, like the opening, again to "Across $110^{\text {th }}$ Street," towards the end of which Grier begins to silently mouth the lyrics, absolutely evoke blaxploitation cinema through the celebratory and iconographic manner in which they present Grier, the great blaxploitation icon, but they do so without employing the style of any specific blaxploitation films of filmmakers. This is not the case in Kill Bill or Inglourious Basterds where, as the subsequent chapters will illustrate, Tarantino's cinephilic film style will make further significant progressions. 


\section{Chapter Three: Kill Bill (2003-2004) and the Aesthetic of Acquisition}

As the film that first significantly manifested the director's cinephilia on the level of style, as opposed solely to the level of diegetic textual referencing, Jackie Brown marked a major turning point in Quentin Tarantino's oeuvre. Six years later, his directorial follow-up Kill Bill —released in two volumes six months apart in October 2003 and April 2004 — went radically further, foregrounding his love for the medium to a practically unprecedented degree. Jenna Ng, who calls Kill Bill "the most prominent example to date of intertextual/cultural referencing," points out that "it is difficult to find a review of Kill Bill which does not refer to the potluck party of Japanese samurai films, Shurayukime (Japan: Toshiya Fujita, 1973, Lady Snowblood) revenge flicks, anime aesthetics, Japanese monster classics, Shaw Brothers kung fu productions, Sergio Leone spaghetti westerns, etc. that the film happily hosts." ${ }^{~}{ }^{3}$ Indeed, textually, thematically, and formally Kill Bill is a film that is veritably suffused with cinephilia, so much so in fact that Geoffrey O'Brien suggests that Tarantino, "a director peculiarly inspired by place, whether the warehouse in Reservoir Dogs or the shopping mall in Jackie Brown or the nightclub in Kill Bill," has with Kill Bill arrived at place where, "he finally needs to invent a cultural space in which his movies can exist. Here he has woven it out of strips of old celluloid." ${ }^{64}$ Where Jackie Brown referenced certain films textually and evoked the blaxploitation subgenre through its 1970 s Soul music soundtrack and the visual depiction of Pam Grier, Kill Bill explicitly renders Tarantino's love for the cinema itself by virtue of its aesthetic of acquisition.

\footnotetext{
${ }^{63} \mathrm{Ng}$, Jenna. "Love in the Time of Transcultural Fusion: Cinephilia, Homage and Kill Bill." Cinephilia: Movies, Love and Memory. Amsterdam University Press, Amsterdam, 2005: 71.

${ }^{64}$ O'Brien, Geoffrey. "Devotional Furies." Film Comment. Nov/Dec 2003: Vol. 39, No. 6: 25.
} 
In describing his own work in Kill Bill, Tarantino suggests that his film "has the same relationship with '70s Grindhouse cinema that Raiders of the Lost Arc (Steven Spielberg, 1981) had with 1940s and late '30s movie serials” and argues that like Spielberg and George Lucas who "had a love for this cinema growing up and took the parts of it they liked the best" and "reinvented it and made it work, not only for a new audience, but just for an audience that wasn't as familiar with it as they are... that's what I tried to do with all the grindhouse exploitation cinema I loved." 65 While the comparison Tarantino offers is certainly valid, he is markedly more explicit in the manner in which his cinephilia manifests itself in his film than were Spielberg or Lucas in theirs. Indeed, Tarantino's love for the cinema is expressed in three primary ways in Kill Bill. First, the diegetic textual references which filled his earlier work still play a part here; second, certain of his character and casting choices evoke earlier works in a manner somewhat analogous to the casting of Pam Grier in Jackie Brown; and third, he here begins the process of significantly referencing specific stylistic techniques employed in previous films.

In her review of the film, Kim Newman points out that Kill Bill "is littered not with verbal references to other films and TV shows but with visual and musical evocations of other works" and suggests that this is evidence of the fact that Tarantino "is maturing technically, no longer relying so much on his motormouth dialogue." ${ }^{66}$ This assessment is largely accurate as the combined 247 minutes of the two volumes of the film feature relatively few such diegetic references. Vol. 1 's lone exception-a reference to a line from Star Trek II: The Wrath of Khan (Nicholas Meyer, 1982)— is not really an

\footnotetext{
${ }^{65}$ Quentin Tarantino Interview for "The Making of Kill Bill: Vol. 1." Kill Bill: Vol. 1 DVD. Alliance Atlantis, 2004.

${ }^{66}$ Newman, Kim. “Kill Bill Vol. I: Review.” Sight \& Sound. Dec 2003: No. 12: 40.
} 
exception at all as it comes in the form of an opening title before the diegesis begins, reading, “'Revenge is a dish best served cold.' (Old Klingon Proverb)." "67 Vol. 2, meanwhile, features a few such references. In the Bride's (Uma Thurman) opening monologue, she declares, "I went on what the movie advertisements refer to as a roaring rampage of revenge," which is a reference to Bury Me an Angel (Barbara Peters, 1972). The rest of the references all occur during the final chapter of the film, fittingly entitled "Final Chapter", with the first occurring during a conversation with the title character Bill's (David Carradine) father figure, Esteban Vihaio (Michael Parks), wherein Vihaio recalls once taking a young Bill to The Postman Always Rings Twice (Tay Garnett, 1946); soon afterwards, the Bride (who by then we have learned is named Beatrix Kiddo) ${ }^{68}$ watches Shogun Assassin (Robert Houston, 1980) with her daughter B.B. (Perla Haney-Jardine); and finally, moments before the final confrontation with Bill, Beatrix says, "I would have jumped a motorcycle onto a speeding train, for you,"69 a reference to Police Story 3 (Stanley Tong, 1992) in which that exact stunt actually occurs. While not absent entirely, such references are few and far between in Kill Bill, therefore locating the brunt of the film's foregrounding of Tarantino's cinephilia in the latter two methods.

The cinephilic gesture in Kill Bill most akin to the treatment of Pam Grier and subsequent celebration of blaxploitation cinema in Jackie Brown, is undoubtedly the casting of David Carradine as the eponymous antagonist of the film. Tarantino constructs an aura of mystery around Bill in Vol. $l$ by presenting him as a shadowy figure whose face is never shown. When he appears in the film, it is in the form of images of his feet

\footnotetext{
${ }^{67}$ Tarantino, Quentin. Kill Bill: Vol. 1. Alliance Atlantis, 2003.

${ }^{68}$ From this point onward I shall employ the moniker "The Bride" when describing the character as she appears in Kill Bill: Vol. $I$ and "Beatrix Kiddo" when describing her as she appears in Kill Bill: Vol. 2 once her true name has been revealed.

${ }^{69}$ Tarantino, Quentin. Kill Bill: Vol. 2. Alliance Atlantis, 2004.
} 
striding up a church aisle, or his hands wiping blood from the face of the Bride, or stroking the pommel and hilt of his 'Hanzo sword', and when his voice is heard it is disembodied with no sight of the mouth that is speaking. By the time he finally appears in Vol. 2 he has therefore been built up as an enigmatic, almost mythical presence by virtue of the manner in which Tarantino has opted to present him stylistically in Vol. 1.

His first appearance in Vol. 2 is similarly spotlighted stylistically. Occurring during the atypically black-and-white opening scene (after the Bride's opening narration) within the chapter entitled "Massacre at Two Pines", Bill's presence is signified first by sound, namely that of the flute he is playing out of sight on the porch of the wedding chapel in which the scene is taking place. The sound of the flute is first heard during a ten-second backwards-tracking, medium close-up shot of the bride slowly walking down the center aisle of the chapel. She stops upon hearing it and an expression of shock and recognition crosses her face as she realizes who is playing and "Il Tramanto" (Ennio Morricone, 1966) begins to play nondiegetically on the soundtrack. There is a brief cut to a shot of the open chapel doorway and then back to the Bride whose surprise transitions gradually to tentatively hopeful happiness. This is followed by a twenty second static shot, again of the open doorway as the Bride slowly walks out on to the porch. Bill is then finally revealed from the side in a brief wide shot which is followed by a series of alternating close-ups (cut with increasing rapidity to match the accelerating tempo of the Morricone song, in one of the film's many passages of Sergio Leone-esque editing) of the Bride's face and that of Bill, playing his flute. As he did with Pam Grier in Jackie Brown, in Kill Bill Tarantino makes a point of stylistically foregrounding the character of Bill and the actor David Carradine who plays him. 


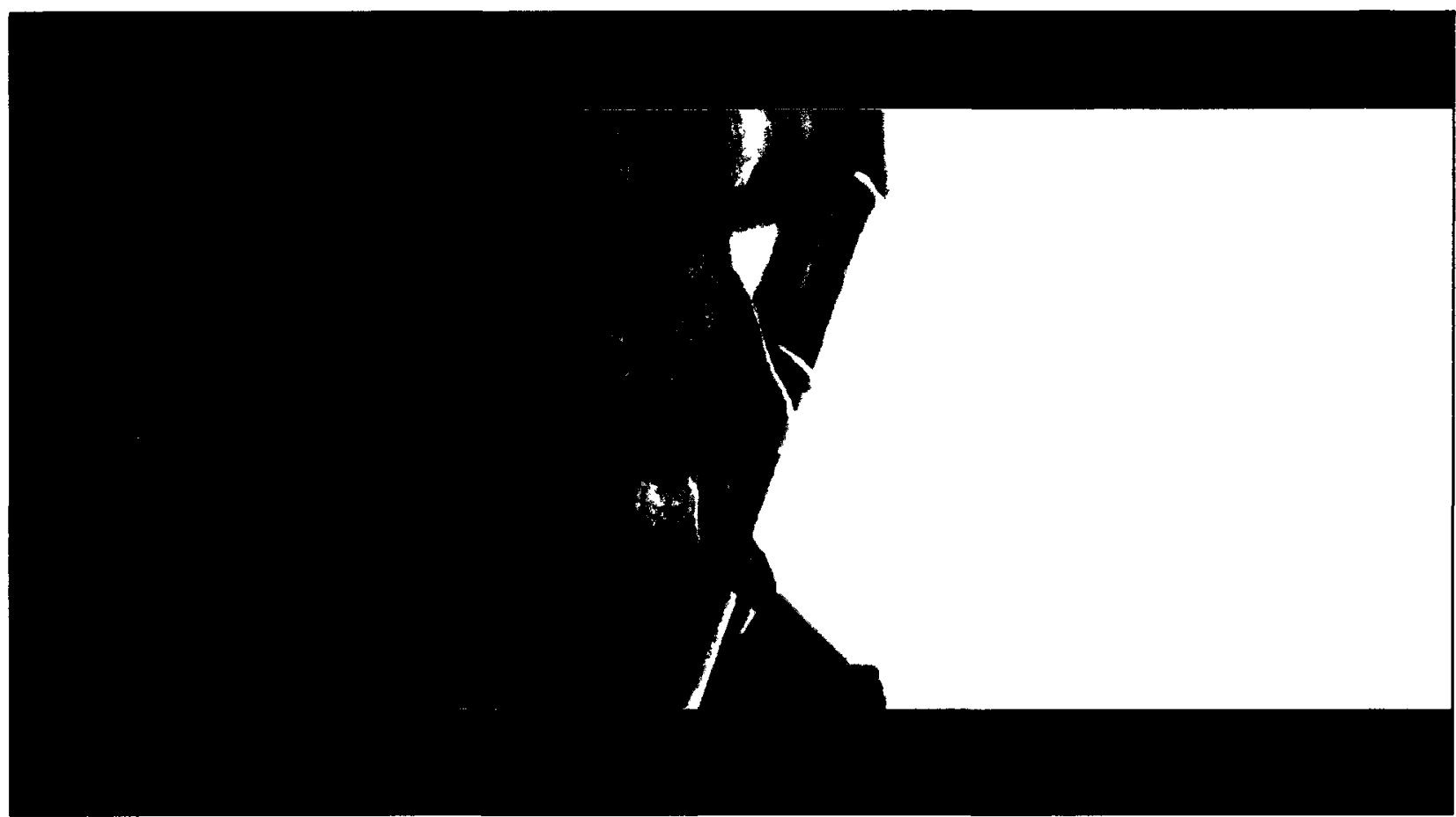

Fig. 3.1: The first onscreen appearance of Bill (David Carradine) in which his face is visible occurs in the opening scene of Kill Bill: Vol. 2, during which he is playing his flute.

The significance of this treatment of Carradine is that, as with Grier, Carradine represents an aspect of Tarantino's cinephilia that he wishes to put on display. In this case it is the television series $K u n g F u(1972-1975)$ a show which Tarantino proudly professes that he "grew up with"70 and which starred Carradine as the lead character Kwai Cheng Cain. In that series Cain frequently played a flute, one of which, Carradine has stated in interviews, is "the flute I'm playing here" of cinephilia on display here is strikingly similar to that which is found in Jackie Brown. Indeed Jenna Ng's statement that “the greater significance in" Tarantino's "employment of Carradine does not so much involve the objective facts of Kung $F u$ or Kwai Cheng

\footnotetext{
${ }^{70}$ Quentin Tarantino Interview for "The Making of Kill Bill: Vol. 2." Kill Bill: Vol. 2 DVD. Alliance Atlantis, 2004.

${ }^{71}$ David Carradine Interview for "The Making of Kill Bill: Vol. 2." Kill Bill: Vol. 2 DVD. Alliance Atlantis, 2004.
} 
Cain as the subjective memories of the television series and in particular Carradine as its star" and that "in light of the signification of Carradine as the actor in Kung $F u$, by casting him as the eponymous character Tarantino thus pays unique tribute by carrying into his film the power of his memories and their inherent affection over and above their inspiration,72 could very easily have been made about Tarantino's employment of Pam Grier in Jackie Brown as well.

Although they are not photographed in the exaltative manner of Pam Grier in Jackie Brown, or enigmatically foregrounded like David Carradine, the prominent inclusion in Kill Bill of the characters Hattori Hanzo (Sonny Chiba) and Pai Mei (Gordon Liu)—along with the casting of the actors who portray them—nevertheless plays a distinctly similar role in its cinephilic evocation of past works. Sonny Chiba, a long time favourite actor of Tarantino's-he was the star of the Street Fighter films referenced in the opening scene of True Romance (1993)—and indeed, of whom Tarantino says, "Sonny Chiba was, to me, right up there in the " 70 s with Charles Bronson and Clint Eastwood as just one of the greatest action stars ever," ${ }^{, 73}$ in the Kill Bill chapter "The Man From Okinawa", portrays the legendary blacksmith Hattori Hanzo whose 'Hanzo swords' are reputed to be the finest blades on the planet, so much so that they take on a supernatural character. Indeed, after being commissioned by the Bride to craft such a blade in aid of her quest for vengeance, Hanzo claims, "If on your journey you should encounter God, God will be cut." ${ }^{, 74}$ What is interesting, however, is that in the 1980 s Chiba starred in the Japanese television series Shadow Warriors (1980-1985) in which he played a character named Hattori Hanzo. As each subsequent season of the series came

\footnotetext{
${ }^{72} \mathrm{Ng} 73$.

${ }^{73}$ Tarantino Interview. "The Making of Kill Bill: Vol. 1." Kill Bill: Vol. 1 DVD.

${ }^{74}$ Tarantino, Quentin. Kill Bill: Vol. 1. Alliance Atlantis, 2003.
} 
out (there were four) he played a new generation of the Hanzo character, a concept Tarantino adopted in his casting of Chiba in his film, of which the director says, "He's Hattori Hanzo the $100^{\text {th }}$ in Kill Bill. ${ }^{, 75}$

A very similar scenario, albeit with an interesting twist, exists with regards to the character of Pai Mei and the actor Gordon Liu who plays him in the chapter entitled "The Cruel Tutelage of Pai Mei." In Tarantino's film, Pai Mei is the Head Priest of the White Lotus Clan as well as an ancient and legendary martial artist. It is from him that Beatrix receives much of her martial arts training including learning the "Five-Point-PalmExploding-Heart-Technique" which, as Bill explains during Vol. 2, is, "quite simply, the deadliest blow in all of martial arts, ${ }^{, 76}$ and which Beatrix eventually uses to defeat Bill. As in the case of Hattori Hanzo however, as Tarantino says, "The character Pai Mei is not an original character. He was in a bunch of Shaw Brothers films before." 77 The difference here is that Gordon Liu was a young man during the period in which the Pai Mei character recurred in Shaw Brothers films and therefore never played him. However, in Fists of the White Lotus (Lieh Lo, 1980), Liu played a young martial artist named Hong Wen-Ting and he fought against Pai Mei (Lieh Lo). Therefore, in Kill Bill Tarantino foregrounds yet another dimension of his cinephilia by casting Liu to play the role of a character he fought in another of the films the director admires. The uniquely cinephilic dynamic that is struck both here and in the case of Hattori Hanzo is astutely described by Jenna Ng, who writes, "Tarantino employs a unique strategy to pay tribute to the era's Asian films and genres: he continues their stories as legends to inform the mythological world of Kill Bill, thus invoking nostalgia not as a petulant lament but as a

\footnotetext{
${ }^{75}$ Tarantino Inverview. "The Making of Kill Bill: Vol. 1." Kill Bill: Vol. 1 DVD.

${ }^{76}$ Tarantino, Quentin. Kill Bill: Vol. 2. Alliance Atlantis, 2004.

${ }^{77}$ Tarantino Interview. "The Making of Kill Bill: Vol. 2." Kill Bill: Vol. 2 DVD.
} 
force to be called up via the echo of mythic power, whereby the stories of the era become the cosmic vision of his film."78 Indeed, in infusing the mythology of his film with references to other films, Tarantino, in effect, roots the core of his film in the cinema itself.

An additional significant factor with regards to the scenes involving Pai Mei is that they are a prominent example of the aesthetic of acquisition which is widely employed in Kill Bill. As Tarantino says, "the whole Pai Mei sequence we shot exactly like the Shaw Brothers films" manifestation of Tarantino's love for the cinema that is apparent in this film, namely the widespread and explicit stylistic citation he employs here for the first time. Dave Brown suggests that with the Pai Mei sequence "Tarantino tries to recreate" the "viewing "pleasure"" of the "badly dubbed, poorly shot" martial arts films that were shown to Western audiences "during the eighties and the video boom" by using "a combination of dubbing, downgrading film stock and some outrageous acting from Liu." ${ }^{80}$ Indeed, the entire sequence has the washed out, grainy appearance of $16 \mathrm{~mm}$ film stock and Tarantino employs the "Shaw Brothers' snap zoom"81 technique of zooming in sharply on Pai Mei's face to accentuate certain of his reactions and expressions. The effect here is that Tarantino's affection for Shaw Brothers Kung Fu films is expressed, not only through his use of the Pai Mei character and casting of Gordon Liu, but also through the style with which he shoots the sequence.

\footnotetext{
${ }^{78} \mathrm{Ng} 72$.

79 Tarantino Interview. "The Making of Kill Bill: Vol. 2." Kill Bill: Vol. 2 DVD.

${ }^{80}$ Brown, Dave. "Tarantino and the Re-Invention of the Martial Arts Film." Metro. 2006: No. 148: 102.

${ }^{81} \mathrm{Ng} 72$.
} 


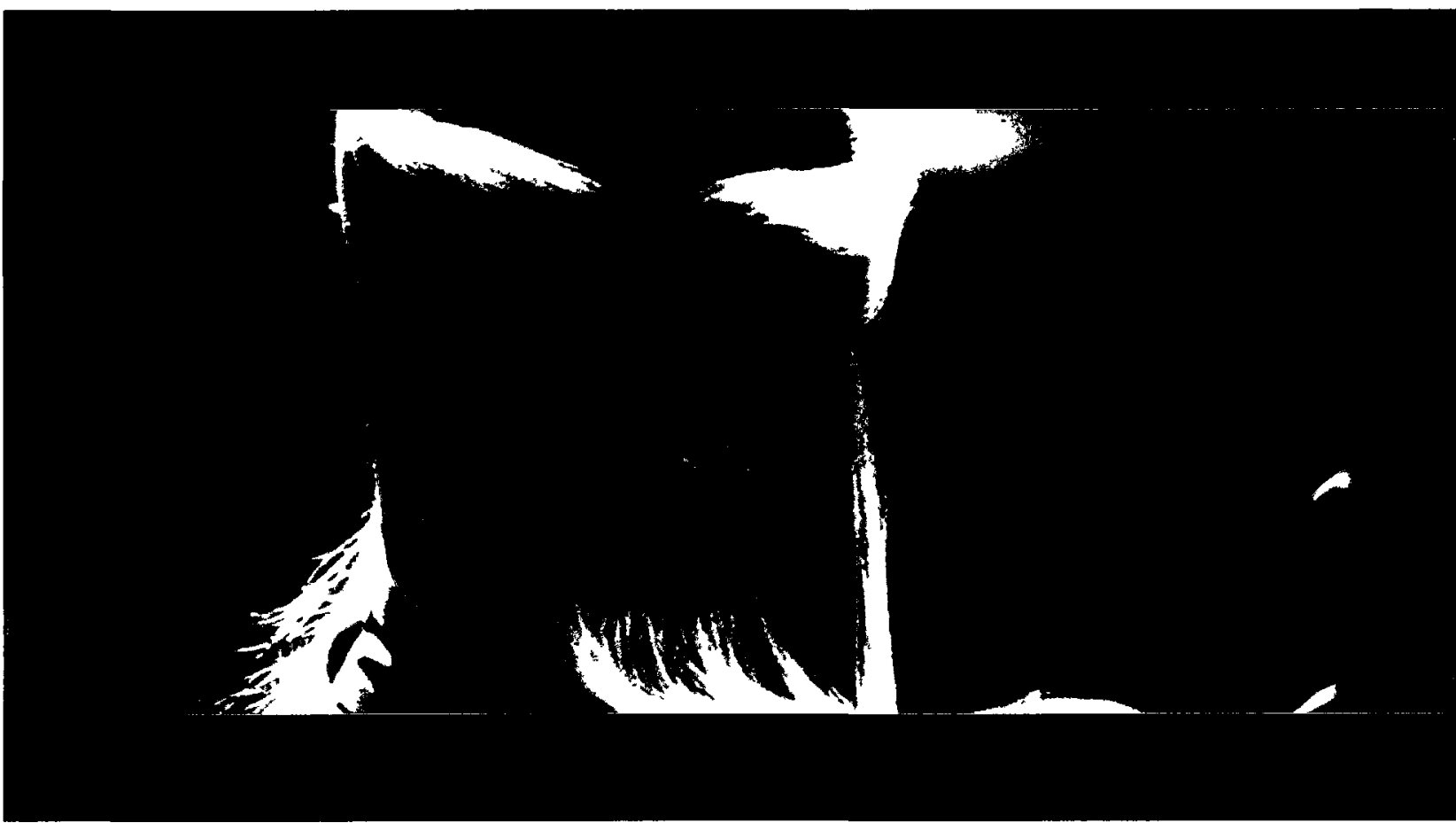

Fig. 3.2: In the Chapter Entitled "The Cruel Tutelage of Pai Mei" downgraded film stock, dubbing, snap-zooms, exaggerated acting from Gordon Liu (here shown) and other techniques are employed to evoke Shaw Brothers Kung Fu films.

Edward Gallafent suggests that film style itself is, from the very start of the film, of pivotal importance to Kill Bill. He points out that "the fuzzy sound and wobbly image of the Shawscope and 'Our Feature Presentation' screens" of the film's opening credits "are followed a little later by the opposite mode" as "exemplified by the high quality of modern sound reproduction, here the perfect clarity of Nancy Sinatra's performance of 'Bang Bang' (appropriately chosen, because so precisely enunciated by the singer, every consonant present) played over the credits." He further suggests that what this indicates is that the film promises "that we are going to be offered a film that will foreground cinematic techniques, both new ones and some that have a past." ${ }^{82}$ Indeed, these past techniques that Tarantino adopts for Kill Bill are nigh innumerable, filling "every

\footnotetext{
${ }^{82}$ Gallafent, Edward. Quentin Tarantino. Harlow, England: Pearson Education Limited, 2006: 101.
} 
frame," $" 83$ as Dave Brown indicates, and, according to Geoffrey O'Brien, marking "the return with a literal vengeance of Tarantino the demonic video store clerk, enamoured of the grainy unrecoverable epiphanies of lost drive-ins and Chinatown movie theatres and all-night gore fests." 84

A complete compendium of the films stylistically invoked in Kill Bill may be, as Theresa Duncan asserts, "part of the fun" of watching it, but it is also, as she acknowledges, "a seemingly infinite task." 85 Indeed, what here follows will hardly be an exhaustive accounting of the vast entirety of the films and styles that Tarantino's film employs, but will instead focus on several primary examples. It will, therefore, be useful to identify the overarching ideology according to which these stylistic references are utilized. In describing the first time he heard the song "The Lonely Shepherd" (Gheorghe Zamfir), which is used in the film during the end of the Bride's visit to Hattori Hanzo in Vol. 1 as well as during that volume's end credits, Tarantino says, "When it was played for me, it was like, this is amazing! This is Japanese samurai meets Sergio Leone Ennio

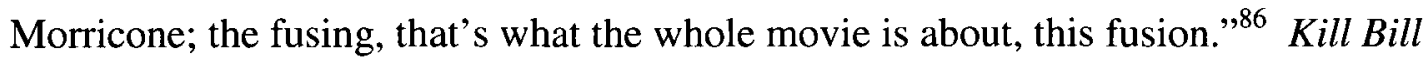
exists as a unique fusion of east and west, of Japanese Samurai films, Hong Kong Shaw Brothers Kung Fu movies, Westerns of both the American and Italian variety and an assortment of other cinematic types, all brought together under one banner in what Chris Norris describes as "an ode to 'hybrid vigour,' the idea that a mixed breed is more rather than less robust." $" 87$

\footnotetext{
${ }^{83}$ Brown 100.

84 O'Brien 22.

${ }^{85}$ Duncan, Theresa. "Twin Bills." Artforum International. Feb 2004: Vol. 42, No. 6: 46.

${ }^{86}$ Tarantino Interview. "The Making of Kill Bill: Vol. 1." Kill Bill: Vol. 1 DVD.

${ }^{87}$ Norris, Chris. "Mixed Blood." Film Comment. Nov/Dec 2003: Vol. 39, No. 6: 26.
} 
As in Jackie Brown, part of this evocation is accomplished through the soundtrack which evokes numerous types of cinema: the Spaghetti Western with the aforementioned "Il Tramanto" from The Good, the Bad, and the Ugly (Sergio Leone, 1966), "Death Rides a Horse" (Ennio Morricone) from Death Rides a Horse (Giulio Petroni, 1969), "Il Mercenario" (Ennio Morricone) from A Professional Gun (Sergio Corbucci, 1968), “A Silhouette of Doom" (Ennio Morricone) and "The Demise of Barbara and the Return of Joe" (Ennio Morricone) from Navajo Joe (Sergio Corbucci, 1966), "The Grand Duel" (Luis Bacalov) from The Grand Duel (Giancarlo Santi, 1972), and "The Summertime Killer" from The Summertime Killer (Antonio Isasi-Isasmendi, 1972); the Japanese Samurai film with "Flower of Carnage" (Meiko Kaji) from Lady Snowblood (Toshiya Fujita, 1973); Hong Kong Shaw Brothers Kung Fu movies with "Super 16" (Neu!) from Master of the Flying Guillotine (Jimmy Wang Yu, 1976); Italian Giallo Horror with "Seven Notes in Black" (Vince Tempura) from The Psychic (Lucio Fulci, 1977); American blaxploitation cinema with "Police Check Point" (Harry Betts) from Black Momma, White Momma (Eddie Romero, 1972) and "Three Tough Guys" (Isaac Hayes) from Three Tough Guys (Duccio Tessari, 1974); British psychological thrillers with “Twisted Nerve" (Bernard Hermann) from Twisted Nerve (Roy Boulting, 1968); and television with "Ironside" (Quincy Jones) from Ironside (1967-1975) and "Flight of the Bumblebee" (Al Hirt) from The Green Hornet (1966-1967). Such an eclectic collection of disparate tracks is emblematic of the incredible variety of the stylistic types employed in Kill Bill and when it is further considered that even sound effects such as those of swinging swords and thrown axes are sampled from The Five Venoms (Cheng Cheh, 
1978), the result is a film that, as Chris Norris argues, “isn't simply referential—a collection of jump cuts from genre to genre-but a true and disorienting fusion." 88

Although the entirety of Kill Bill features a generous cross-pollination of stylistic evocations, there is a distinctive difference between Vol. 1 and Vol. 2. As Tarantino says, "Vol. 1 was mostly Japanese Samurai and Hong Kong Kung Fu films, with a little bit of Spaghetti Western. Here (Vol. 2), this is much more the Spaghetti Western." ${ }^{89}$ Indeed, this is an accurate breakdown of the films although it is hardly an ironclad delineation. The overarching Spaghetti Western feel of Vol. 2 notwithstanding, it is in that volume where the "Cruel Tutelage of Pai Mei" chapter-the most explicitly Shaw Brothers Kung Fu-esque sequence in the film—takes place. And while Vol. 1 is far more eastern in its stylization, it does feature the portion Tarantino mentions in the previous quote, a scene in the chapter entitled "The Blood Spattered Bride" which is set in El Paso, Texas and very much stylized in a Western fashion. Nevertheless, these prominent exceptions aside, the demarcation between the two volumes is a solid general guideline.

The single film most explicitly invoked in Kill Bill and certainly in Vol. 1 , is Japanese director Toshiya Fujita's 1973 revenge themed Samurai picture Lady Snowblood. There are obvious plot parallels between the two, as each involves a young female warrior with a list of enemies against whom they are out for revenge. More interesting are the stylistic evocations of the Japanese film in Kill Bill. Yuki, the protagonist of Lady Snowblood wears a kimono that is very similar to one worn by ORen Ishii (Lucy Liu) in Kill Bill and both characters come to similar ends in similar snowy settings at the film's conclusion (O-Ren dead at the Bride's hand, Yuki seemingly

\footnotetext{
${ }^{88}$ Norris 28.

${ }^{89}$ Tarantino Interview. "The Making of Kill Bill: Vol. 2." Kill Bill: Vol. 2 DVD.
} 
dead at the hand of the daughter of one of the men she kills). The two films each feature, in the ostensibly 'real' world, what Edward Gallafent identifies as "some of the terms of" Japanese anime, namely "freeze frame, and blood presented as floods or geysers." Indeed, the decapitations and dismemberments along with the cartoonish spurting of blood which results in Kill Bill seem to be a definite reference to Lady Snowblood. Additionally, in Lady Snowblood, when Yuki spots one of her targets the camera zooms in rapidly on her face, a technique which is also employed in Kill Bill when the Bride sights one of her enemies, although in this case things are not so simple.

The Bride's initial sightings of her enemies provide a useful example of one of the ways in which stylistic appropriation functions in Kill Bill. Whereas the zooming in on the face of the avenging protagonist is a common feature of both Tarantino's film and Lady Snowblood, in Kill Bill there is considerably more at play. When the camera zooms in on the Bride's face, the image also takes on a distinctively red tint, while a flashback of the incident that triggered the Bride's quest for revenge - the murder of her fiancé, wedding party, and (she believes) her unborn daughter-is superimposed over the image of her face. This simultaneously invokes Marnie (Alfred Hitchcock, 1964) in which the screen would flash red signifying repressed trauma whenever the protagonist Marnie (Tippi Hedren) saw something that was vividly red; and Giulio Petroni's Death Rides a Horse where a flashback of the massacre that haunts the protagonist is depicted with reddish orange tinting. Additionally, during these moments in Kill Bill an alarm sound fills the soundtrack which is actually part of the Quincy Jones song "Ironside" from the television series of the same name. In this way, Tarantino's aesthetic of acquisition

${ }^{90}$ Gallafent 109. 
simultaneously invokes no fewer than four disparate sources in a single moment, synthesizing them into a fusion that results in a style transcending them all.

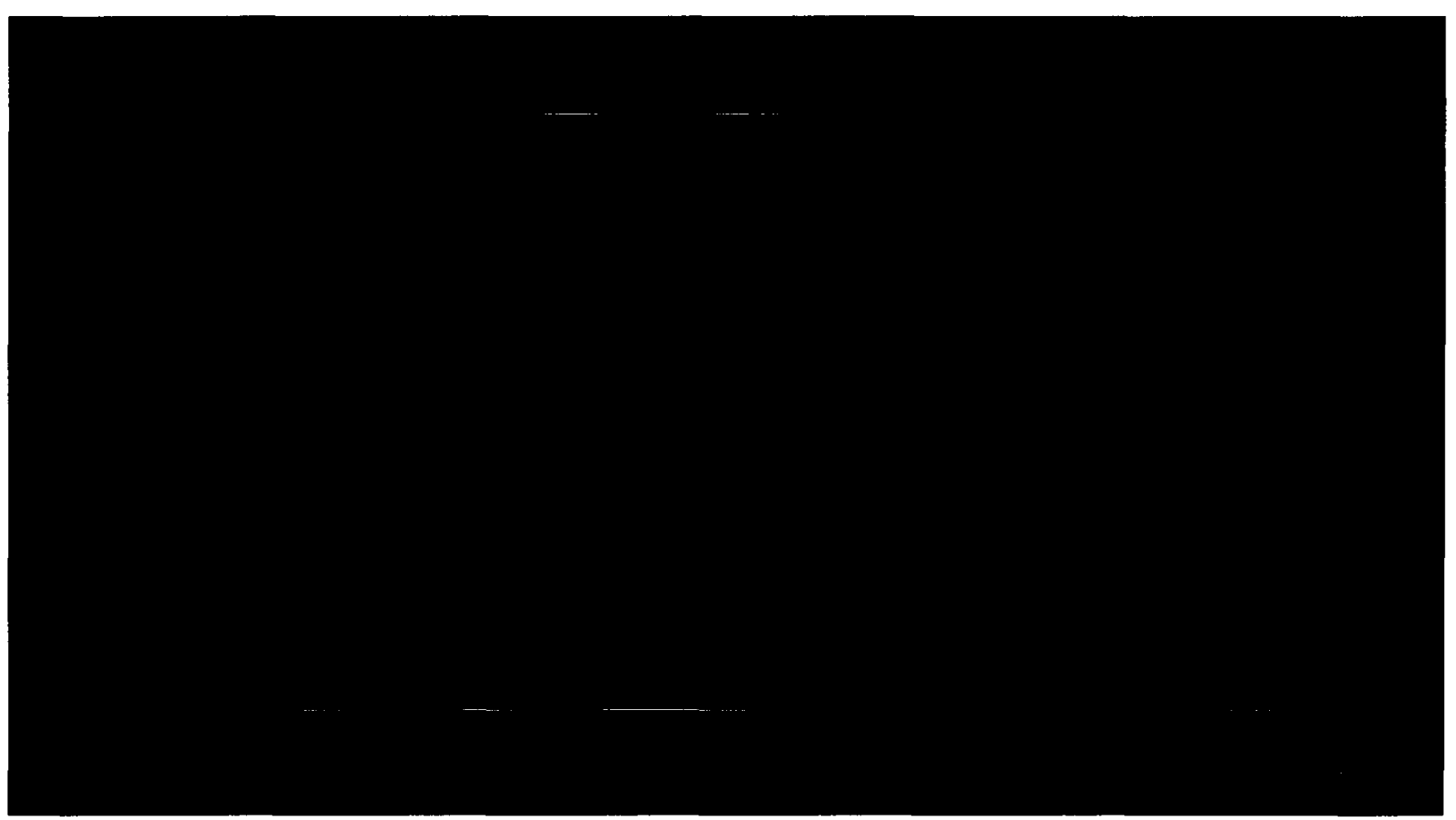

Fig. 3.3: In a single instant Tarantino invokes the styles of Lady Snowblood, Marnie, Death Rides a Horse, and Ironside, ultimately transcending all of them.

Another interesting fusion of styles in Kill Bill: Vol. 1 occurs late in the chapter "Showdown at House of Blue Leaves" during the final confrontation between the Bride and O-Ren Ishii. As previously mentioned, this encounter occurs in a snowy, Japanese setting reminiscent of the one that concludes Lady Snowblood and the additional fact that it is a samurai duel concluding in the bloody demise of one of the combatants further establishes the link between the two films. This duel, however, is stylistically handled in a manner reminiscent of a Western showdown, particularly of the sort that typified the conclusion of Sergio Leone's Spaghetti Westerns. As with the iconic final duel in Leone's The Good, the Bad, and the Ugly which is cut in accordance with the rhythms of the song "The Trio" (Ennio Morricone, 1966) on the soundtrack, the duel in Kill Bill is 
also set to music. And although the song to which the Kill Bill duel is set, "Don't Let Me Be Misunderstood" (Santa Esmeralda, 1977), has no association with the Spaghetti Western genre, its implementation serves a similar tempo setting function in Tarantino's film.

Comparative cinemetric analyses of these showdowns will provide useful data in determining the manner in which Tarantino invokes Leone's duel with his own. The showdown in Leone's film lasts 5 minutes and 30 seconds and is spread over 92 shots with an average shot length of 3.6 seconds. Tarantino's duel, on the other hand, has a duration of 8 minutes and 20 seconds and is spread over 85 shots with an average shot length of 5.9 seconds. On the surface, these numbers appear quite different and would seem to objectively contradict the subjectively experienced similarity between the two scenes. However, a closer look at the data is illuminating. Each scene begins with a slow pace of cutting - the first 15 shots of the Leone scene have an average shot length of over 9 seconds while the same span in Tarantino's film features an average shot length of just over 8 seconds—but from that point on the two scenes follow different, but related trajectories. The scene in The Good, the Bad, and the Ugly proceeds to steadily accelerate in pace over the next 60 shots, ratcheting up the tension and culminating in 13 consecutive shots of less that 1 second in duration immediately before the first, and fatal, shot is fired by The Man With No Name (Clint Eastwood). 


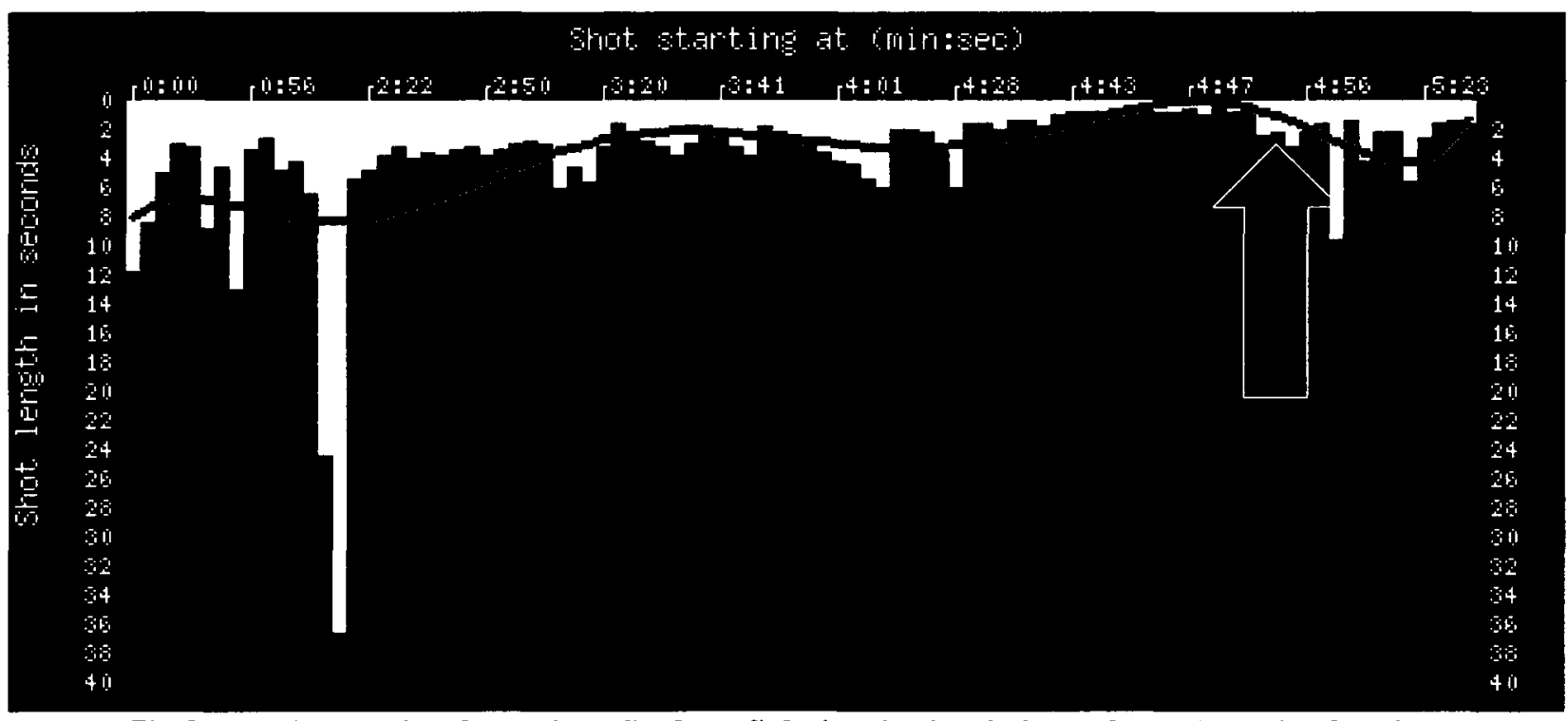

Fig 3.4: A cinemetrics chart of the final gunfight in The Good, the Bad and the Ugly wherein the first gunshot is denoted by a yellow arrow.

When considered in the light of the inherent difference between a contest of blades and one of guns, an understanding of Tarantino's approach crystallizes. Whereas the Leone duel culminates in a single killing shot (followed by a few others for good measure), Tarantino's involves a number of exchanges and interludes. With that fact in mind, Tarantino's invocation of Leone's style becomes apparent. The cutting pace in the Kill Bill duel is marked by a cycling of accelerating rapidly cut portions with segments that feature substantially longer shots. The reason for this is that as the combatants clash, Tarantino invokes a Leone-esque accelerating editing style up to the point where one fighter or the other strikes a blow. Each time that occurs, the two duellists separate and there is a brief, more deliberately cut, reprieve before the next clash. The result is a more slowly cut scene overall due to the interludes of longer shots, and a fascinating fusion of Italian Western and Japanese Samurai film styles. 


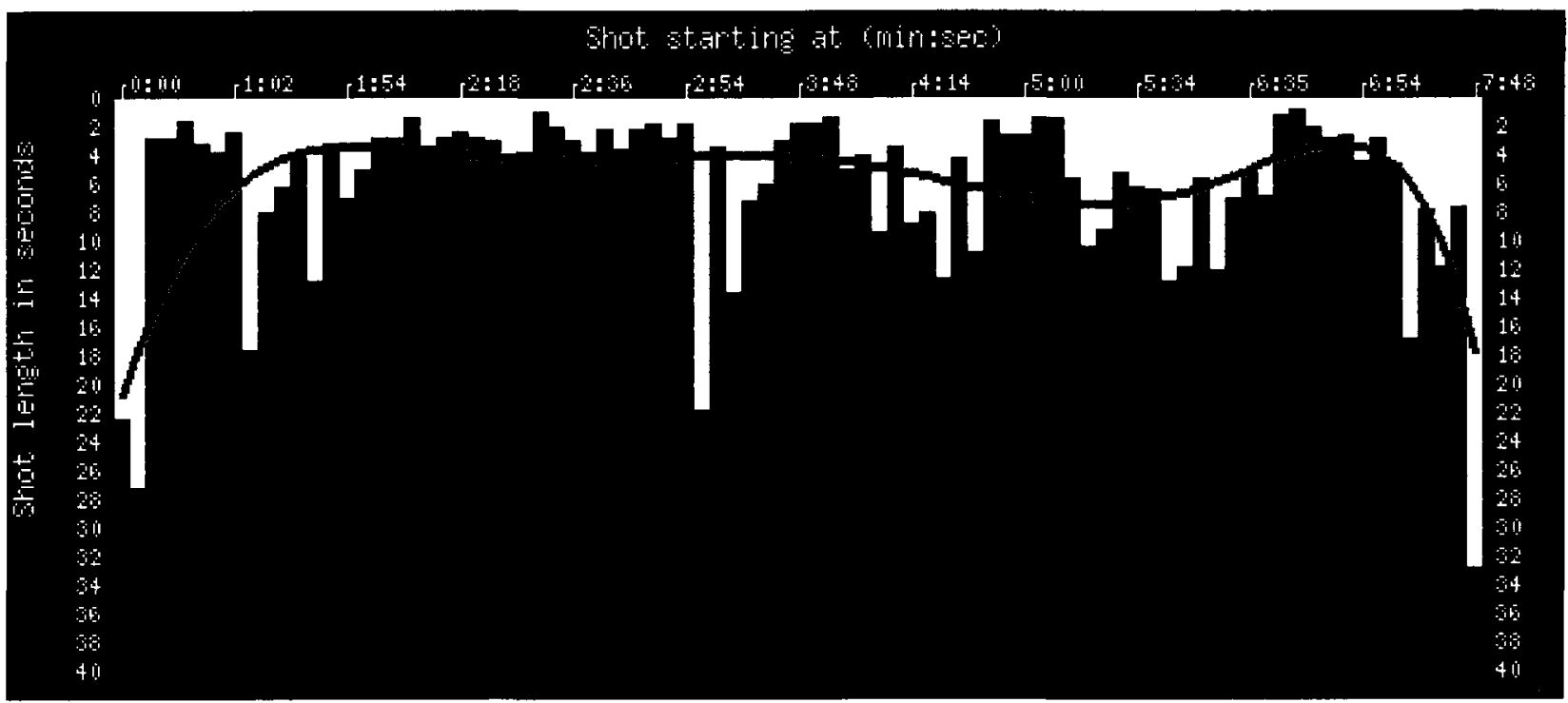

Fig. 3.5: A cinemetrics chart of the Samurai duel between the Bride and O-Ren Ishii in Kill Bill: Vol. 1.

That the invocation of Spaghetti Westerns becomes much more explicit in Vol. 2 is clear when one compares the final confrontation between the Bride and Elle Driver (Daryl Hannah) in the chapter "Elle and I" to the one with O-Ren Ishii. Preceded by a brutally visceral sequence of hand-to-hand combat in a filthy mobile home, the sequence in question begins when both combatants acquire a weapon, again, as in the fight with $\mathrm{O}$ Ren, samurai swords. Once more the scene is set to music, but this time the song that is used is Ennio Morricone's “A Silhouette of Doom” from Sergio Corbucci's Spaghetti Western Navajo Joe. This time also, although the weapons being used are still swords as opposed to guns, the editing far more explicitly references Sergio Leone than did the ORen sequence. Comprising 66 shots over a duration of 3 minutes and 4 seconds with an average shot length of 2.8 seconds and a comparatively slowly cut first minute and a half followed by rapid acceleration of the editing pace culminating in a single precise strike due to the tight fighting conditions (the plucking out of Elle's eye), the evocation of Leone is here so explicit as to be utterly unmissable. 
While the overarching ideology of a fusion of east and west is certainly evident in the film style of Kill Bill, it is important to point out that Tarantino's aesthetic of acquisition is hardly limited exclusively to that organizing principle. Indeed, Tarantino stylistically foregrounds his affection for a wide range of cinema and a final example will be useful here to demonstrate that fact. In Kill Bill: Vol. 1 during the chapter entitled "The Blood Spattered Bride" there is a scene during which the Bride is lying comatose in the hospital and Elle Driver is dispatched by Bill to assassinate her by lethal injection as she sleeps, a mission Bill calls off at literally the last second as the stopper is about to be pushed on the syringe. The scene depicts Elle's entrance into the hospital and then tracks smoothly down the hallway for 15 seconds to the room in which the Bride lies. At that point a split screen technique is used, in the left screen showing various views of the comatose Bride, and in the right screen depicting Elle putting on a nurse's uniform disguise and preparing the syringe with an unidentified red poison, before tracking along in front of her until she arrives at the Bride's room at which point, after a 1 minute duration, the split screen technique ceases. All the while Elle has been whistling an ominous tune with nondiegetic accompaniment.

The split screen technique invokes Dressed to Kill (Brian De Palma, 1980) which featured an extensive split screen sequence of the psychotic Dr. Robert Elliott (Michael Caine) listening to a voicemail message his transsexual alternate personality had left on his answering machine in regards to the prostitute Liz Blake (Nancy Allen) that 'she' is stalking and planning to murder, meanwhile that very prostitute inhabits the other half of the split screen conducting a series of phone conversations. De Palma's film also featured a scene in which the camera tracked down a hallway following a nurse, but the 
more likely reference in this case is the American thriller Black Sunday (John

Frankenheimer, 1977) in which an assassin disguised as a nurse attempts to commit murder at a hospital with a syringe of red poison. When it is further considered that the tune Elle whistles in Kill Bill is Bernard Hermann's "Twisted Nerve" from the British psychological thriller of the same name, it becomes clear that here is a further example of a complex fusion of disparate film styles (this time not as a part of the East/West paradigm) within Tarantino's aesthetic of acquisition.

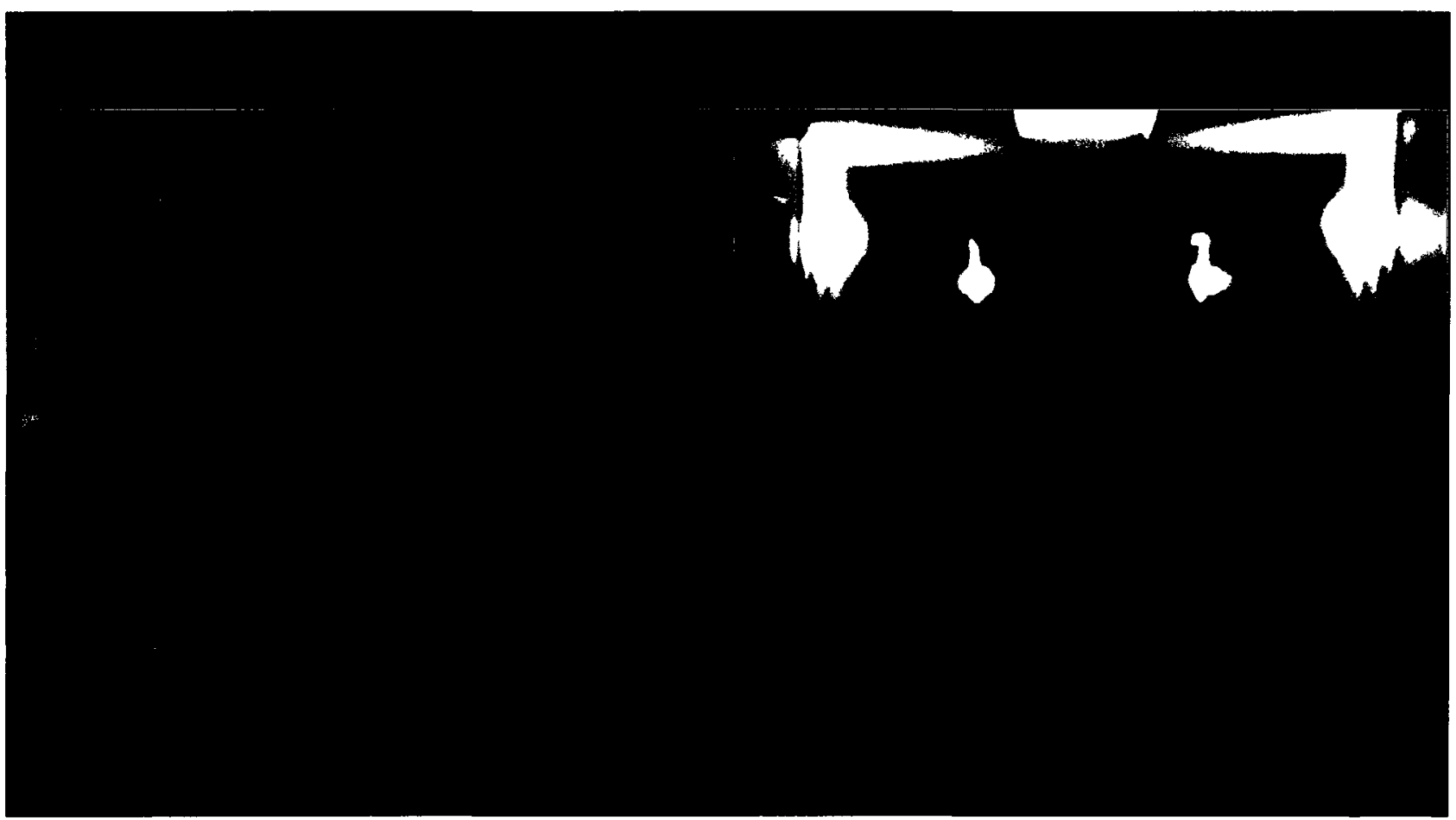

Fig. 3.6: In a single scene, Tarantino synthesizes the styles of Dressed to Kill, Black Sunday, and Twisted Nerve.

One might ask what precisely the point is of this relentless invocation of past films and film styles. Indeed, Howard Hampton has dismissively suggested that “Tarantino's massive, two-part uber-B-movie is a celluloid python that lovingly devours tons of lumpish reference points without ever establishing a persuasive reason for 
being." 91 I might suggest that what Jenna Ng describes as "the sheer love that underpins"92 Tarantino's stylistic references may be point enough. After all, when as amorphous a concept as love is able to be demonstrated in concrete terms as it is within Tarantino's film style, there is an innate value to that. There is, however, I think one more valuable point to be made here. As Edward Gallafent writes, "Perhaps the final way of thinking of these 247 minutes of film is that they represent a remarkable and-in terms of current practice-a very unusual celebration of a single female star." Indeed, comparing Tarantino's depiction of Uma Thurman in Kill Bill to the treatment of Marlene Dietrich in The Scarlet Empress (Josef Von Sternberg, 1934), Gallafent further suggests that "here as there, a film seems to be given over to the opportunities to photograph one face, its masks and its moods: innocent, guilty, shocked, bloodied, soiled, unspotted, in colour, in black and white." 93 I described something very similar, albeit with a differing focus, regarding Tarantino's visual depiction of Pam Grier in Jackie Brown, and will be identifying additional similar cases in Inglourious Basterds (Quentin Tarantino, 2009). One of the points I intend to demonstrate is that that film is very much about the power of the cinema, an extension perhaps of what Gallafent suggests Tarantino's invocation of past films accomplishes in Kill Bill. In describing the very end of the film he writes, “Tarantino's insistent reach back into Hollywood's past is marked in a number of details of the presentation of these end credits. He might want to say, this is what the camera could always do, and can still do: to represent the individuality of one human being in

\footnotetext{
${ }_{92}^{91}$ Hampton, Howard. "Extreme Prejudice.” Film Comment. Nov/Dec 2005: Vol. 41, No. 6: 52-53.

${ }^{92} \mathrm{Ng} 71$.

${ }^{93}$ Gallafent 120 .
} 
such a way as to bring it, and the power of this medium, home to us." ${ }^{.94}$ And that is point enough indeed.

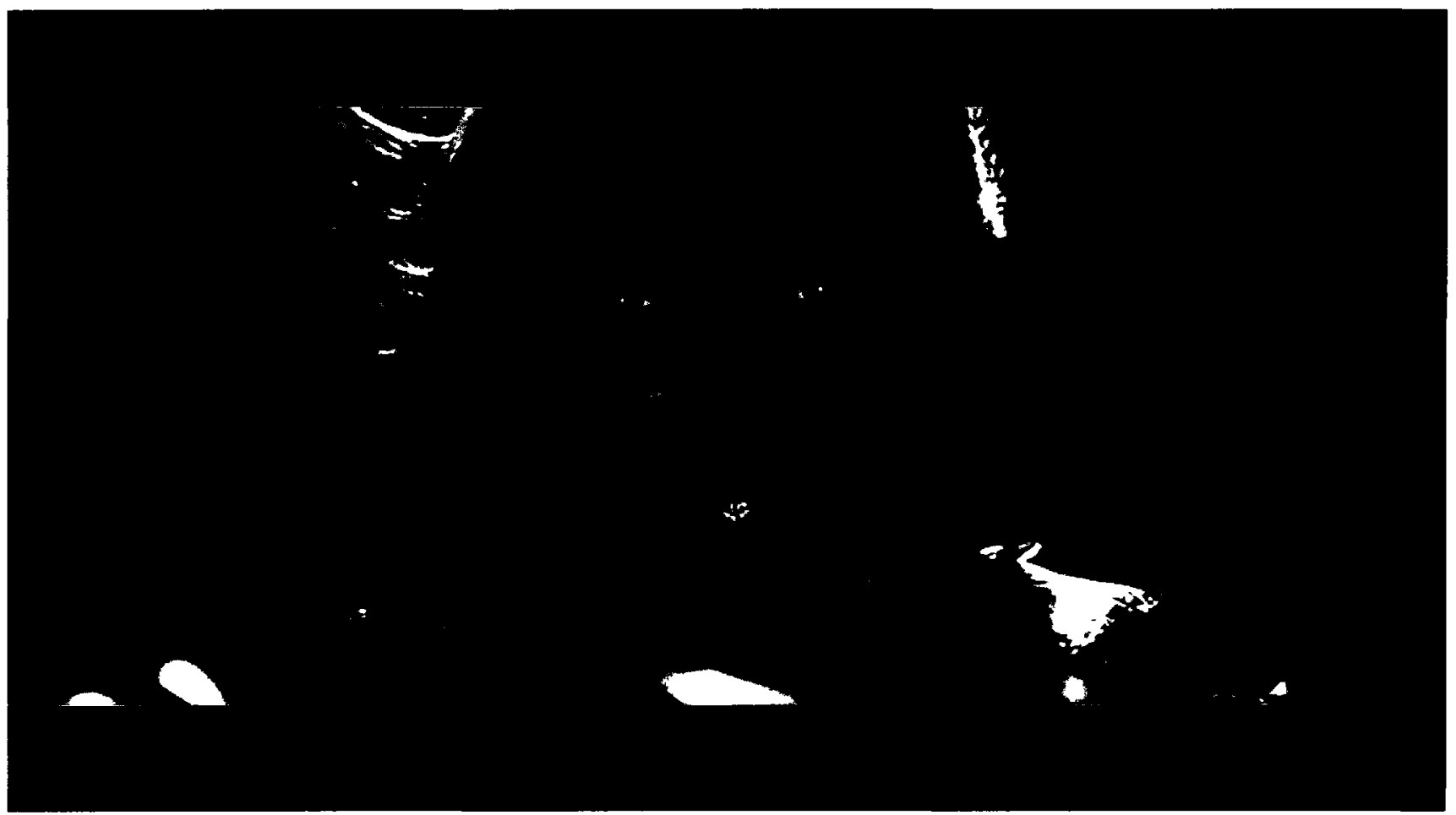

Fig. 3.7: Tarantino's invocation of past films and film styles towards the celebration of his actress, in essence, celebrates the capabilities of the medium itself.

${ }^{94}$ Gallafent 120 . 


\section{Chapter Four: Inglourious Basterds (2009): The Diegetization of Cinephilia and the Power of the Medium}

Quentin Tarantino's directorial follow-up to Kill Bill was Death Proof (Quentin Tarantino, 2007), an experiment in sheer exploitation cinema that became one half of the double feature Grindhouse (2007) which he co-authored with Robert Rodriguez whose Planet Terror (Robert Rodriguez, 2007) comprised the other half of the twin bill. Unlike Jackie Brown or Kill Bill (for all the ways they stylistically evoked other films), Death Proof was essentially an example of the director indulging in the basest form of his cinephilia in order to produce an actual grindhouse exploitation film. Of far greater interest for my current purposes is Tarantino's subsequent and latest work Inglourious Basterds. In essence as explicitly cinephilic as Kill Bill, the methods of foregrounding the director's cinephilia are here nonetheless more nuanced, and in ways anticipated by Jackie Brown. Indeed, if Death Proof could be seen to represent the director's cinephilia at its most bluntly simplistic, Inglourious Basterds represents the exact opposite, the most sophisticated and potent example to date of the cinematic representation of Tarantino's love for the cinema.

Writing on the film in the wake of its premiere at the Cannes film festival in 2009, Scott Foundras indicates that "in Inglourious Basterds, the world of cinema is, for the first time, the primary reality of the film as well as its primary subtext."95 And indeed, while Tarantino's love for the cinema has been a constant presence throughout his films, whether through the diegetic textual references which have consistently peppered his works from the beginning, the stylistic evocations that first came to prominence in Jackie Brown, or the widespread stylistic citations which typify Kill Bill's aesthetic of

\footnotetext{
${ }^{95}$ Foundras, Scott. "Kino Über Alles." Film Comment. July/Aug 2009: Vol. 45, No. 4: 32.
} 
acquisition, in Inglourious Basterds the director's cinephilia finds its most cogent manifestation. The cinephilic elements that have typified his previous films again come into play here, but with two primary differences. First, Tarantino's cinephilia is here diegetized to an unprecedented degree; and second, of primary thematic interest in Inglourious Basterds is the power of the cinema itself.

The cinephilic references of Tarantino films past, which had often amounted to little more than winking nods, are here virtually extinct. The title of the piece is a misspelled tip of the cap to The Inglorious Bastards (Enzo G. Castellari, 1978) and as Kim Newman points out, Tarantino also pays tribute to "Mexican actor Hugo Stiglitz, who appeared in Italian pictures such as Nightmare City (Incubo sulla citta contaminate, 1980)" by naming a character in Inglourious Basterds after him and coupling his first appearance in the film with "a freeze frame introductory billing with a distinctive soundtrack sting." ${ }^{96}$ In a similar vein, the name of the character Lieutenant Aldo Raine (Brad Pitt) is an acknowledgement of one of the director's favourite actors from exploitation films of the 1960s and 1970s, Aldo Ray. These rare exceptions aside however, the vast majority of Tarantino's foregrounding of his cinephilia in this film primarily takes the form of stylistic evocations of the sort found in Jackie Brown and Kill Bill, diegetized textual references (not to be mistaken for the diegetic textual references which dominated his earlier works) and representational content, as well as subtextual thematic substance.

\footnotetext{
${ }^{96}$ Newman, Kim. "Inglourious Basterds." Sight \& Sound. Sept 2009: Vol. 19, No. 10: 73.
} 
Ryan Gilbey has claimed that Inglourious Basterds is "a spaghetti western draped in a Second World War greatcoat" ${ }^{\prime 97}$ and indeed, although he disputes the suggestion that such a descriptor typifies the entire film, Tarantino acknowledges that "there definitely is, in the first two chapters, an idea of doing a spaghetti western with World War II iconography." 98 As displayed on the opening title card, Chapter One of the film is subtitled "Once upon a time... in Nazi-occupied France" a clear invocation of the spaghetti western Once Upon a Time in the West (Sergio Leone, 1968). The evocation of Leone is further cemented when the film opens on the first scene, that of a farmer, Perrier LaPadite (Denis Menochet), chopping wood while his daughter hangs clothing on a line.

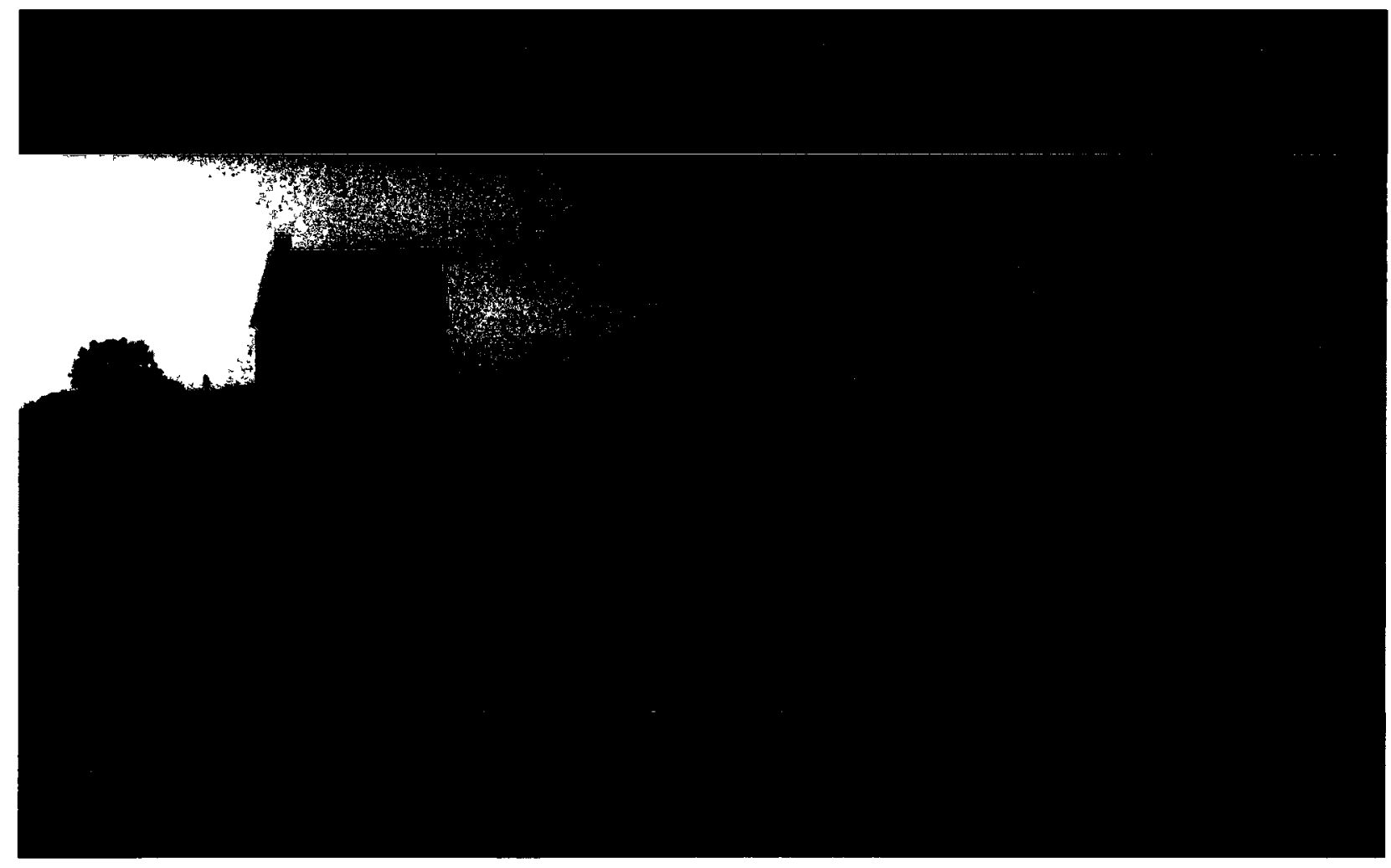

${ }^{97}$ Gilbey, Ryan. "Quentin Tarantino: The Golden Boy Must Make Good." The Observer. May 3, 2009: 31.

${ }^{98}$ Tarantino, Quentin. Interview with Ryan Gilbey. "Days of Gloury." Sight \& Sound. Sept 2009: Vol. 19, No. 9: 18. 
Fig. 4.1: The isolated farmstead setting that opens Inglourious Basterds is one of the many elements that give the film's opening stanzas the feeling of a spaghetti western with World War II iconography.

Upon hearing a sound, the daughter pulls aside the sheet she is hanging, revealing the approach of a Nazi cavalcade. As she does so, the song "The Verdict" (Ennio Morricone), originally from the spaghetti western The Big Gundown (Sergio Sollima, 1966), begins to play and, as Nick James says, "Though we're looking at a farm on a French hillside, where a narrow eyed, sweat-soaked farmer is chopping wood as a German military car with two motorcycle outriders approaches, the music and the camera angles evoke Leone."99 Tarantino concurs, stating, "Even with the Nazi uniforms, even with the motorcycles and the car, it doesn't break the western feel. It almost adds to it in a strange, shouldn't-work-but-does kind of way. It just feels like a western."100

Tarantino does not simply homage Leone through his visual style, but also seems to take a page from the Italian's book in terms of how he constructs certain of his scenes, the first chapter of Inglourious Basterds included. Describing the manner in which Tarantino prolongs scenes in order to heighten tension, David Bordwell writes:

You may remember the bursts of violence, but what he fashions most lovingly is buildup. Here the spirit of Leone hovers over our director. In each entry of the Dollars trilogy, you can see the rituals of the Western getting more and more stretched out, filled with microscopic gestures and eye-flicks. Eastwood's lips stick slightly together and must peel apart when he speaks: This becomes a major event. I'm a primary-document witness to the fact that 1969 cinephiles were stunned by the long opening scene of Once Upon a Time in the West, which after painstakingly establishing the tics of several characters ends by eliminating them. Later, John Woo gained fame by dwelling on Homeric preparations for combat and endlessly extended bouts of gunplay. From these masters Tarantino evidently learned the power of the slow crescendo and the sustained aria. ${ }^{101}$

\footnotetext{
${ }^{99}$ James, Nick. "Carve His Name With Pride." Sight \& Sound. July 2009: Vol. 19, No. 7: 18.

${ }^{100}$ Tarantino Interview. Sight \& Sound: 18.

101 Bordwell, David. "(50) Days of summer (movies), Part 2." Observations on Film Art. 12 Sept 2009,

27 Nov 2010: <<http://www.davidbordwell.net/blog/?p=5446>>.
} 
The scene that is, in Inglourious Basterds, being 'built up' is, essentially, the introduction of the character Colonel Hans Landa (Christoph Waltz) of the SS, known throughout France by his unofficial title, The Jew Hunter. Nick James describes Tarantino's presentation of Landa as "an intimidating presence on a par with Lee Van Cleef at his most civil" ${ }^{102}$ and indeed, Landa's introduction here is very reminiscent to the first appearance of the character Van Cleef played in The Good, the Bad, and the Ugly (Sergio Leone, 1966), Angel Eyes.

In Leone's film, Angel Eyes is introduced in an 11 minute and 10 second sequence located at the hacienda of a man he has been hired to kill. Over the course of that duration, Angel Eyes first intimidates the man and extracts some information before finally killing him. All the while, Leone creates an atmosphere of heightening tension by employing long passages marked by a conspicuous lack of dialogue, relying for their effect, as Bordwell says, "chiefly on imagery and music." ${ }^{103}$ Strikingly similarly, the opening scene in Inglourious Basterds, devoted as it is to the introduction of Landa, is 18 minutes in duration and also features a steady racheting up of tension before a violent conclusion (the murder of the Jewish family, the Dreyfuses, whom LaPadite has been concealing). The primary difference, of course, is that where Leone's sequence heightens tension in the absence of dialogue, Tarantino's principally accomplishes this through it, namely, through an ingeniously structured dialogue driven multilingual interrogation. As Bordwell says, while Tarantino "is no slouch" in either the imagery or music departments which Leone masterfully employs, "he relies, like his beloved pulp writers, on talk."104

\footnotetext{
${ }^{102}$ James 18.

${ }^{103}$ Bordwell.

${ }^{104}$ Bordwell.
} 


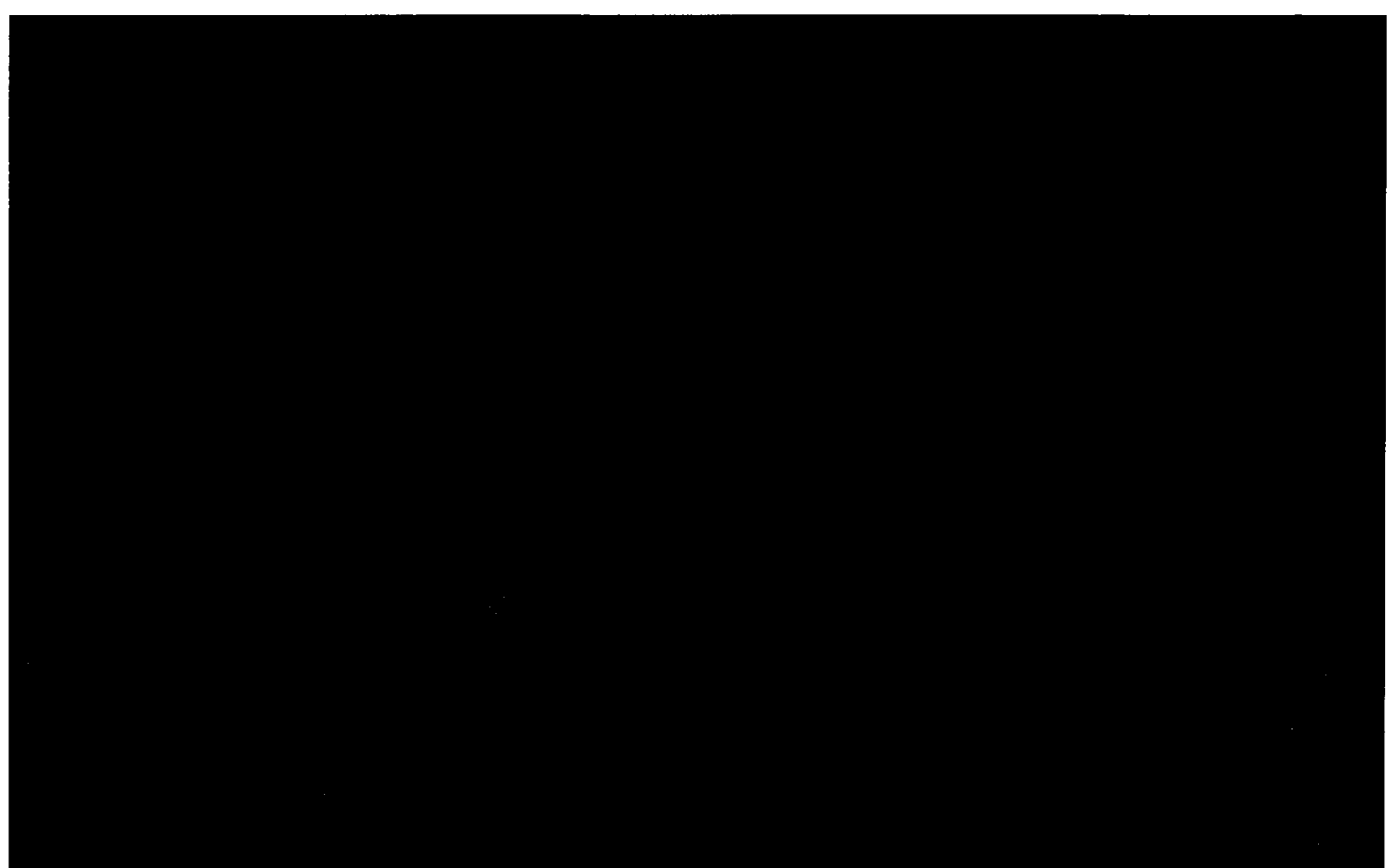

Fig. 4.2: The first chapter of Inglourious Basterds is devoted to the introduction of film's principle antagonist, Col. Hans Landa and is reminiscent of the introduction of Angel Eyes in The Good, the Bad, and the Ugly.

Tarantino suggests that the film's second chapter "Inglourious Basterds", devoted to the introduction of the eponymous American Nazi-killing military squadron, "feels even more like a spaghetti western insofar as it has that comic brutality, black humour, gallows humour, the bloodthirsty jokes, the Morricone music" but insists that after that point the film "becomes something else."105 And indeed, observing the rest of the film bears this suggestion out. While containing resemblances to "bunch-of-guys-go-towar" ${ }^{106}$ movies such as The Dirty Dozen (Robert Aldrich) and The Inglorious Bastards, from which Tarantino's film derives its name, and vague plot similarities to To Be or Not to $\mathrm{Be}$ (Ernst Lubitsch, 1942) in which members of a Polish acting troupe are forced to

\footnotetext{
${ }^{105}$ Tarantino Interview. Sight \& Sound: 18.

${ }^{106}$ Tarantino Interview. Sight \& Sound: 18.
} 
employ their theatrical skills in order to impersonate Nazi officers, Inglourious Basterds generally eschews further evocations of the spaghetti western genre. The cinema, however, continues to be invoked, and fervently so, as after spending the two, spaghetti western inspired, opening chapters introducing the principle characters, Tarantino engages the engine of his narrative, one fuelled by the unprecedented diegetization of his cinephilia.

Describing the prominent role the cinema plays in the film world of Inglourious Basterds, Thomas Doherty writes, "Movie titles, garish posters, and once top-billed names flash by between lessons in the flammability of nitrate film stock, the processing of magnetic soundtracks, and the editing of $35 \mathrm{~mm}$ footage (hands on, kids, with adhesive tape, not AVID software). Max Linder gets a call-out and Emil Jannings a cameo, but Leni Riefenstahl, alas, appears only on a marquee as the snow-swept mountain girl in G.W Pabst and Arnold Fanck's White Hell of Pitz Palu."107 Indeed, the title of the film's third chapter "German Night in Paris" is itself an emblem of the diegetized cinephilia that will typify much of the film from that point onward. It refers to what immediately follows, a scene that opens with the lone Jewish survivor of the film's opening massacre, Shosanna Dreyfus (Melanie Laurent), preparing to remove White Hell of Pitz Palu (G.W Pabst, 1929) from the marquee of a Parisian movie theatre which has just hosted a German Night. Taking place in 1944, four years after the scene in which her family was murdered by the Nazis, Shosanna is living in Paris under the alias Emmanuelle Mimieux — passing successfully as a gentile by virtue, perhaps, of her blonde hair and fair complexion-and the theatre in question is hers, left to her (so she claims) by her late aunt. She is set upon by a young German soldier who is an admirer of her theatre (and

${ }^{107}$ Doherty, Thomas. "Inglourious Basterds." Cineaste. Winter 2009: 59. 
her) with whom she conducts a brief discussion of Leni Reifenstahl (the star of White Hell of Pitz Palu) for whom she tactfully expresses disdain, and of the director G.W Pabst who she respects, despite his being German, because she is French, and, as she says, "We respect directors in our country... even Germans."108

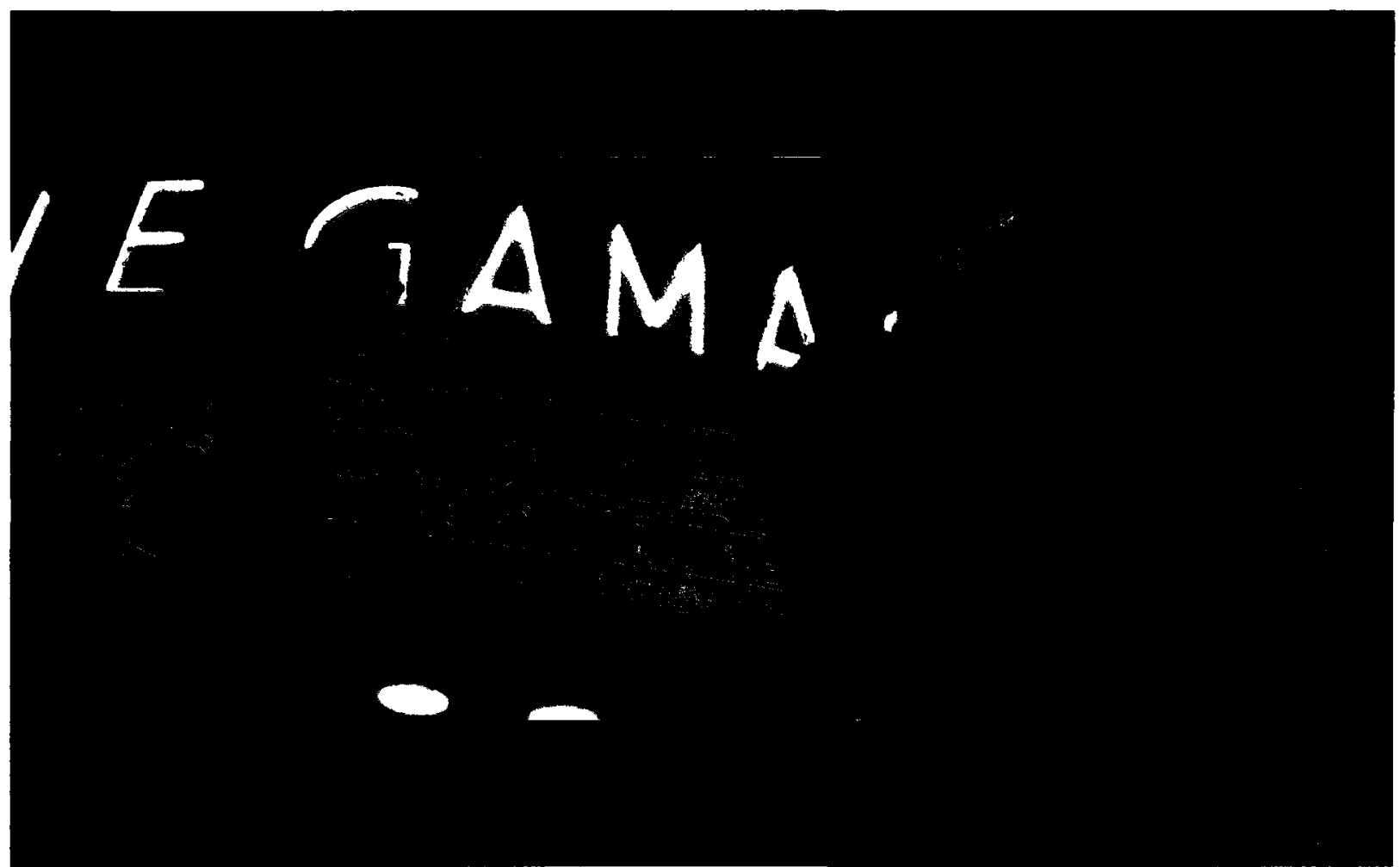

Fig. 4.3: In Inglourious Basterds Tarantino diegetizes his love for the cinema by giving the medium of film itself a significant plot function.

In previous Tarantino films such an exchange might stand out from the whole as a blatant example of the director's cinephilia surfacing. In Inglourious Basterds the cinephilia is no less blatant (indeed it is perhaps even more salient than in the earlier films). But it has been diegetized (the conversers are a cinema owner and one of her patrons). Indeed, as

\footnotetext{
${ }^{108}$ Tarantino, Quentin. Inglourious Basterds. Alliance Films, 2009.
} 
Ben Walter says, with Inglourious Basterds "cinema provides not only incidental references: it is also the meat of the plot.",109

Describing this latest manifestation of Tarantino's cinephilia, Walters notes that while “the heroines of Death Proof (Tarantino's half of the Grindhouse double bill) were stuntwomen by profession; here (in Inglourious Basterds), nearly everyone works in movies."110 Indeed, the young soldier with whom Shosanna speaks turns out to be Private Fredrick Zoller (Daniel Brühl), a German war hero turned movie star whose exploits are being celebrated in Joseph Goebbels' (Sylvester Groth) new film Nation's Pride, where Zoller will portray himself. Zoller's attraction to Shosanna and his affection for her theatre inspire him to convince Goebbels to stage the premiere screening of the film at her theatre. This is envisioned as a gala event to bolster the pride of the German military and as such the entire German High Command will attend. This screening becomes the crux of the second half of the film, as Shosanna conspires with her lover Marcel (Jacky Ido), the projectionist of her theatre, to burn the theatre down while the Nazis are inside; using what Thomas Doherty describes as "the perfect symbolic accelerant," $11135 \mathrm{~mm}$ Nitrate film stock as a fuel source. This event also becomes the point at which the film's various plot streams connect, as British intelligence, having learned of this screening, collaborates with the Basterds on a scheme of their own.

Code-named "Operation Kino" the British/American plan involves infiltrating the Nazi premiere, also with the intention of blowing it up, by posing as a German film crew. Since this, as the character General Ed Fenech (Mike Meyers) says, "requires a

\footnotetext{
${ }^{109}$ Walters, Ben. "Debating Inglourious Basterds." Film Quarterly. Winter 2009-2010: Vol. 63, No. 2: 20.

${ }^{110}$ Walters 20.

${ }^{111}$ Doherty 60.
} 
knowledge of the German film industry under the Third Reich,"112 they bring in to head the mission Lieutenant Archie Hicox (Michael Fassbender) who, in Tarantino's world, before the war worked as a film critic for the film magazine "Films and Filmmakers" and also published two books on German cinema: "The Art of the Eye and the Path of the Mind" a study of German cinema in the 1920s, and "24 Frame Da Vinci" a subtextual criticism of the work of G.W Pabst. This is the second time Pabst is referenced in Inglourious Basterds and this time the degree to which its diegetization distances it from the typically Tarantinian diegetic reference is even more pronounced. Indeed, Hicox's knowledge of Pabst will be strategically employed later in the film when, upon being challenged on his accent while attempting to pass as a German, Hicox references Pabst's The White Hell of Piz Palu, claiming that he lives in a small village in the shadow of that mountain where everyone speaks with such an accent. By making the film as much about the cinema as its ostensible World War II subject matter, Tarantino finds himself working with something of an ideal setting for the foregrounding of his cinephilia.

A unique example of Tarantino's diegitization of his love for the cinema in Inglourious Basterds, that is nonetheless reminiscent of one of the primary manners in which his cinephilia has manifested ever since Jackie Brown, is found in the character of Bridget von Hammersmark (Diane Kruger). A fictitious German movie starlet, described by Tarantino as "the Dietrich who stayed"113, von Hammersmark is also a British spy and the one who will get the Basterds into the premiere. Tarantino's description of her is quite fitting, as his visual treatment of Kruger here is another in a line of heroines who he has chosen to celebrate on screen. Here is another example of the sort of "very unusual

\footnotetext{
${ }^{112}$ Tarantino, Quentin. Inglourious Basterds. Alliance Films, 2009.

${ }^{113}$ Tarantino Interview. Sight \& Sound: 20.
} 
celebration of a single female star" and the subsequent bringing home of "the power of this medium"114 that Edward Gallafent observes at play in Kill Bill with regards to Tarantino's treatment of Uma Thurman, but even more so, the treatment of Diane Kruger is a definite inheritor of the stylistic celebration that occurred in Jackie Brown with regards to Pam Grier, albeit with an interesting twist.

Not appearing in Inglourious Basterds until 10 minutes into the film's fourth chapter, "Operation Kino", Kruger's von Hammersmark nonetheless makes her first appearance in a now familiarly luxuriated style, a 28 second shot which focuses on her while panning slowly from right to left—bringing her into the center of a frame that originally also contained a young German soldier—and gradually tracking towards her, bringing the shot from a medium close-up of her upper body to a close-up of her face. Tarantino has, himself, acknowledged the invocation of Josef von Sternberg in this scene, citing certain of his shots as the "kind of luxurious" camera moves "von Sternberg would've done" and stating that "if I'm gonna shoot actresses in an exquisite '40s style, who better to look to for inspiration?"115 It is true that von Sternberg's series of films featuring Marlene Dietrich occurred in the 1930s rather than the 1940s, but Tarantino's simultaneous invocations of both of these figures makes the connection clear, and this is the twist on the connection to Pam Grier's treatment in Jackie Brown. Whereas the earlier film celebrated Grier's blaxploitation films by luxuriating in her as an icon for them, in Inglorious Basterds it is not the past oeuvre of the actress Diane Kruger that Tarantino is honouring. Instead, he diegetizes this same sort of celebratory impulse by

${ }^{114}$ Gallafent, Edward. Quentin Tarantino. Harlow, England: Pearson Education Limited, 2006: 120.

115 Tarantino, Quentin. "Interview - Quentin Tarantino on His Movie Influences." Hollywood Teamster. 16 Feb 2010, 27 Nov 2010: < http://moviedriver.wordpress.com/2010/02/16/interview-quentin-tarantinoon-his-movie-influences/ $>$. 
creating, in the character of Bridget von Hammersmark, a surrogate icon within the world of his film. Indeed, in what is perhaps the most complex and fascinating manifestation of his cinephilia in any of his films to date, Tarantino commemorates the cinema of Josef von Sternberg by engaging in a very Sternbergian visual celebration of a female star intended to evoke Marlene Dietrich. ${ }^{116}$

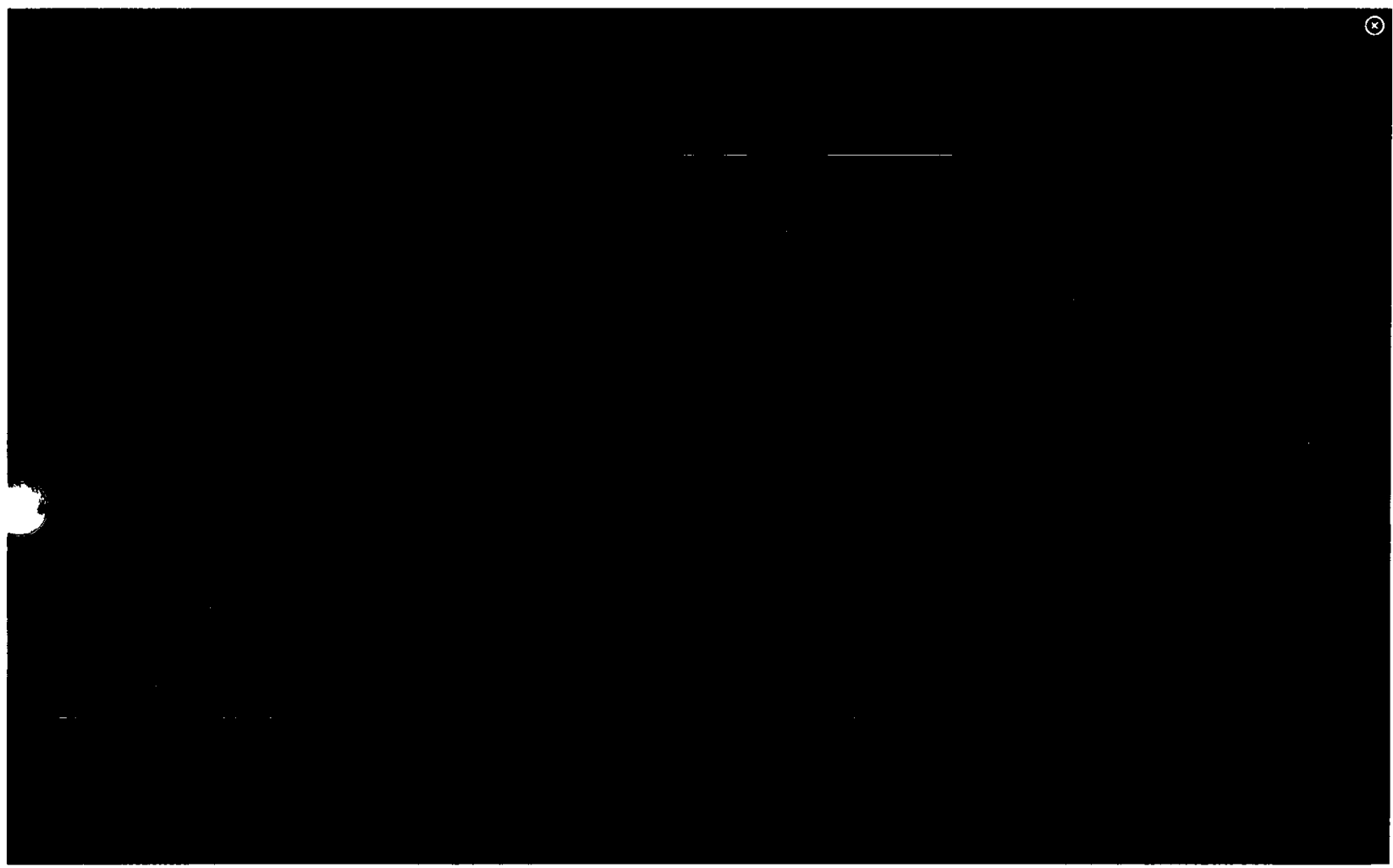

Fig. 4.4: Tarantino celebrates the cinema of Josef von Sternberg by featuring a surrogate Marlene Dietrich in his film in the form of Bridget von Hammersmark and by shooting her in a Sternbergian exaltative style that is also evocative of his own earlier work in Jackie Brown.

\footnotetext{
${ }^{116}$ It should be noted that another, more oblique, reference in this case would be G.W Pabst, Tarantino's affection for whom has already here been established. While the echoes of "Pygmalion" are more conclusively documented with regards to Josef von Sternberg's working relationship with Marlene Dietrich, a very similar dynamic is evident in Pabst's work. The most famous example would be his treatment of Louise Brooks in Pandora's Box (1929) and Diary of a Lost Girl (1929), but similar tendencies can be observed in Joyless Street (1925) with Greta Garbo and The Love of Jeanne Ney (1927) with Édith Jéhanne.
} 
Where in Jackie Brown and Kill Bill, Tarantino focused his camera's affectionate gaze upon a single female character, in Inglourious Basterds there is a second. The film's fifth chapter, "Revenge of the Giant Face," opens with an 11 second wide shot of Shosanna in profile, wearing a red dress, and standing next to and looking out of a circular window. This is followed by a series of three axial dissolves in on her figure. The first, to an 11 second medium shot of the same view; the second, to a 12 second medium close-up; and the third, to a 9 second close-up at the end of which she finally turns away from the window and towards the camera. The first hard cut of the sequence occurs on her movement as she steps towards the camera. The cut is to an 8 second extreme close-up of her face, beginning at her lips and then ascending her face to her eyes. It is then revealed through a series of close-ups that she has moved to a vanity makeup table, as the subsequent shots are of her hands picking up various types of makeup and of her applying said makeup to her face. Included in their number are two additional extreme close-ups, first of her eyes as she applies mascara, then of her lips as she puts on lipstick. It is perhaps the most blatant case to date of Tarantino's camera luxuriating in the female countenance, standing out further from the rest of the film by virtue of the fact that it is the first scene specifically set to a song which runs from start to finish, "Cat People" (David Bowie) from Cat People (Paul Schrader, 1982). Jim Emerson compares this scene to the manner in which Dietrich was shot in Dishonored (Josef von Sternberg, 1931), stating that "Shosanna becomes Dietrich as martyr, warrior... and executioner."117

\footnotetext{
${ }^{117}$ Emerson, Jim. "Cutting the Basterds." Scanners :: Blog. 2 Oct 2010, 27 Nov 2010:
} <<http://blogs.suntimes.com/scanners/2010/10/cutting_the_basterds.html >>. 
Fig. 4.5: Tarantino's camera adoringly depicts the face of Shosanna Dreyfus as she applies makeup as though it were war paint.

That choice of words though, 'martyr', 'warrior', and 'executioner', is indicative of the difference in Tarantino's treatment of Shosanna, who applies her makeup like war paint, as opposed to Bridget von Hammersmark, who is the consummate image of glamour.

While the treatment of the latter was primarily in the service of the diegetization of the director's cinephilia, with the acknowledgement of the power of the medium as a secondary focus, here the situation is reversed; the diegetization of Tarantino's love for the cinema is still on display, but the fifth chapter brings the theme of the power of the cinema forcefully (and brutally) to the fore.

David Bordwell has written that "it's too limiting to see Tarantino's films as merely anthologies of references. I think he wants more"118 and this is certainly the case

\footnotetext{
${ }^{118}$ Bordwell.
} 
in Inglourious Basterds. Bordwell goes on to elaborate, stating, "The young man arrested by great bits from blaxploitation and biker movies sees cinema not as merely piling up cinephiliac references - though that's surely part of it—but as a flow of tingle-inducing gestures, turns of phrase, shot changes, musical entrances. There can be pure pleasure in having time to see how actors move, or savor their lines, or simply fill up physical space by being centered in the anamorphic frame." This is the power of the cinema, right here, and Bordwell's conclusion that "we are to be stirred, enraptured, astonished by a procession of splendors big and small" and that "formal virtuosity isn't necessarily soulless; it can yield aesthetic rapture" ${ }^{119}$ surely lies close to the heart of what draws Tarantino to the cinema, to what draws us all. In his own way, he is expressing both the type of cinephiliac moments Christian Keathley has outlined, and the designed cinephiliac moments I have suggested. The celebration of these moments has marked each of the films covered in this study and with Inglourious Basterds they receive their most thorough celebrating yet. But Tarantino does more as well; he here, perhaps for the first time, also problematizes this power.

Ben Walters suggests that, as early as Pulp Fiction, Tarantino has demonstrated a fascination with the filmmaker's ability to perform miracles, as it were. He writes, "In that film, Vincent (John Travolta) suggests to Jules (Samuel L. Jackson) that miracles happen "when God makes the impossible possible," and Tarantino relishes the storyteller's comparable ability: Vincent, like Melanie (Bridget Fonda) in Jackie Brown, dies, but is resurrected by choppy chronology."120 That same power is demonstrated, but problematized, in the climactic fifth chapter of Inglourious Basterds. The plan to host the

\footnotetext{
119 Bordwell.

${ }^{120}$ Walters $20-21$.
} 
premiere of Nation's Pride at Shosanna's theatre has come to fruition. Adolf Hitler, Joseph Goebbels, Hermann Göring, and Martin Bormann are all serendipitously in attendance and the plans of both Shosanna and the Basterds (unbeknownst to each other) to blow up the theatre are each in action. While the Basterds' methods are standard enough (dynamite strapped to their legs), Shosanna's, as previously described, is more symbolically potent. Behind the screen is an enormous heap of extremely flammable $35 \mathrm{~mm}$ nitrate film stock awaiting the appointed time when a spark is struck that will ignite it (and the theatre) into an inferno. That time is chosen to coincide with an addition Shosanna and Marcel have shot and edited into Nation's Pride, immediately after Zoller-having just spent much of the film gunning down hundreds of American soldiers from a clock tower-looks into the camera and challenges, "Who wants to send a message to Germany?" In their addition, the next cut is to Shosanna's face and she responds, "I have a message for Germany, that you are all going to die, and I want you to look deep into the face of the Jew who is going to do it. Marcel, burn it down"121 at which point, Marcel, the black Frenchman, waiting behind the screen ignites the film stock and the screen erupts into flames and Shosanna's image laughs with sadistic delight as the theatre is consumed.

Immediately before this occurs, however, there is another scene during which Zoller, uncomfortable watching the cinematic recreation of his wartime exploits, excuses himself from the theatre and decides to visit Shosanna in the projection booth. When she denies him entrance, he becomes angry and forces his way in. Knowing that he cannot be allowed to interfere with what is to come Shosanna draws a pistol and shoots him repeatedly. As he slumps to the ground, however, she happens to look out from the

${ }^{121}$ Tarantino, Quentin. Inglourious Basterds. Alliance Films, 2009. 
projection booth to the screen where the image is of Zoller, troubled by the war. Seeing him in this (cinematic) way, it is as if she sees him for the first time, and she turns back to the real Zoller, checking to see if he still lives. As she turns him over, he pulls out his own gun and shoots her to death, before succumbing to his own wounds. Then, shortly after this scene, they are both-first Zoller, then Shosanna-'resurrected' by the power of cinema in the screening of Nation's Pride.

While the similar resurrections in Pulp Fiction and Jackie Brown are gleefully celebrated by Tarantino, here, Ben Walters suggests, the results are significantly more potent:

When it comes, the story's climax is as blunt an assertion of the phantasmagorical power of cinema as the medium has ever delivered. Shosanna and Zoller kill each other but are resurrected as filmic images-themselves agents of death-before flames consume the screen and then the audience. What remains is a weird form of film as fatal dominatrix, a close-up of Shosanna projected onto smoke-the giant face of the chapter's title-laughing as her viewers burn. ${ }^{122}$

In a drastic twist, the cinematic presentation of the actress, which had, to this point, been rejoiced in, takes on a far darker turn. There is still the element of celebration-here Tarantino revels in the idea that cinema can end wars, destroy the Nazis, and rewrite history-but the severe ramifications of such a suggestion hover, quite literally, over the scene. As Charles Taylor writes, "Even after the screen has erupted in flames, Shoshanna's laughing image, now projected on billows of smoke pouring forth from the proscenium, hovers over the doomed audience like an avenging wraith. The scene achieves operatic grandeur; it's an example of the rapture movies are capable of - even as it shows movies themselves employed as an instrument of death."123

\footnotetext{
122 Walters 22.

123 Taylor, Charles. "Violence as the Best Revenge." Dissent. University of Pennsylvania Press: Winter 2010, Vol. 47, No.1: 105.
} 


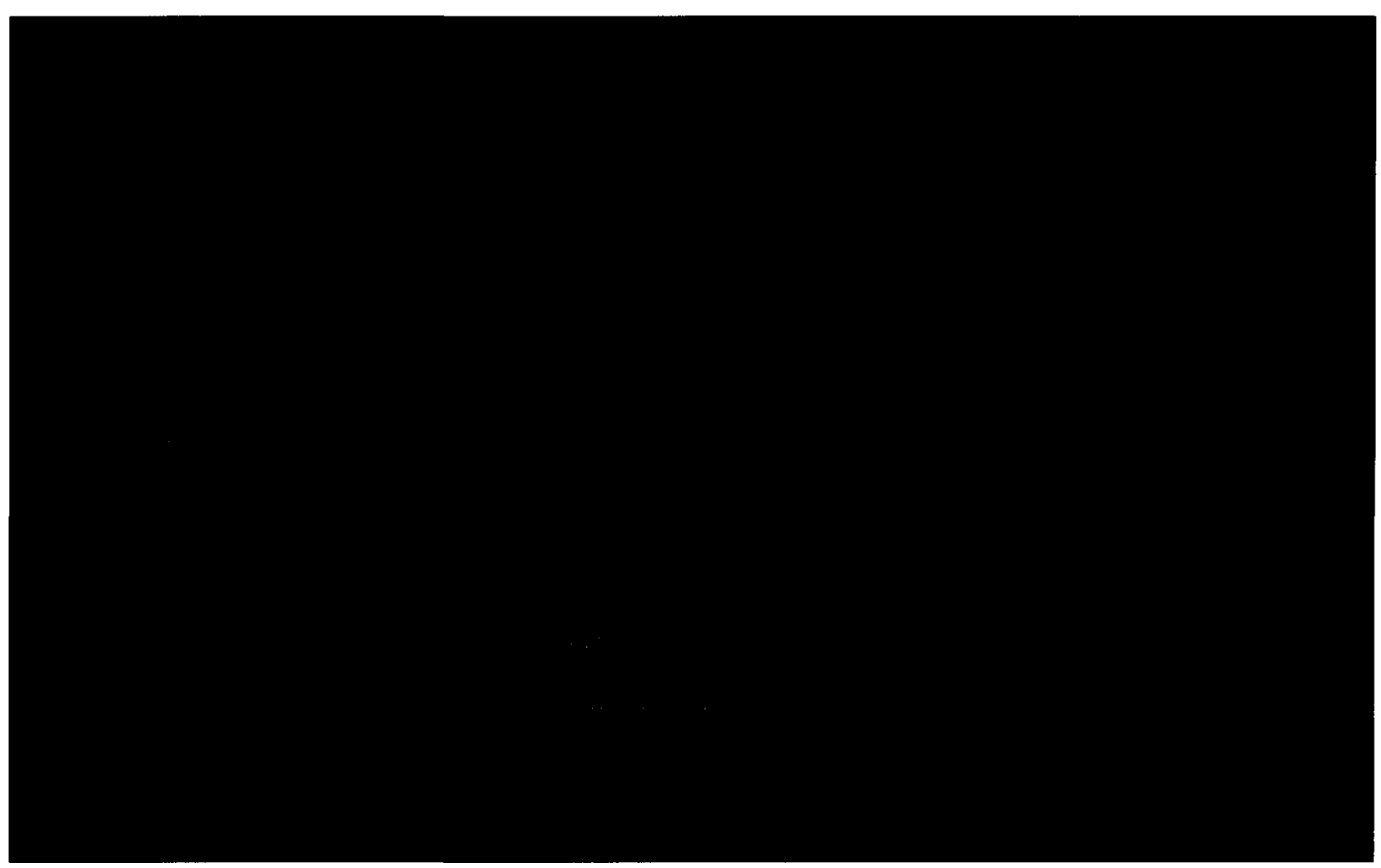

Fig. 4.6: As the theatre burns to the ground with all its inhabitants trapped inside, Shosanna's maniacally laughing visage is projected on the smoke from the fire, in one of the most potent and troubling images of the cinema's power ever presented.

Towards what end though, is this simultaneous celebration and problematization of the power of the cinema? Certain of Tarantino's musings about this scene are helpful in this regard. He says:

For instance, let's contemplate that pile of film stock for a second now. What if that pile of film—and I don't talk about it in the movie, but let's think about it now-what if it is Shosanna's collection of $35 \mathrm{~mm}$ films that've been banned by the Nazis? Let's say that's Grand Illusion. Let's say that's Mayerling, Duck Soup, The Kid. Let's say it's all of those. If that's the case, then it's almost as if Papa Jean Renoir himself is helping to bring down the Nazis! Ok. But now, let's look at the other possibility. Let's say those are all Goebbels' films. You're looking at 300 prints of Nazi propaganda, so now it's Goebbels' own creations that are bringing down the Third Reich... The point being that there's a lot of food for thought there, the more you dig into these metaphors for cinema, the use of the cinema itself, the film stock and so on. ${ }^{124}$

${ }^{124}$ Tarantino Interview. Sight \& Sound: 19. 
Scott Foundras has suggested that “Tarantino's film harbours a subterranean interest in the broader phenomenon of filmed propaganda and historical authorship" ${ }^{125}$ and indeed this seems to fall nicely in line with the director's own statements. The power of film is indiscriminate and as Ben Walters points out "bad guys as well as good can adore and exploit this potency."126 This has been the reality of cinema since its inception and likely will remain so until its demise. That Tarantino now tempers his boundless love for his medium with an acknowledgment of its double-edged nature is a tribute to his progression as an artist.

There is a final point left to be made about the manner in which, as Ben Walters says, "Inglourious Basterds is drenched in cinema to a degree remarkable even for a director defined by his movie love"127 and that point, Charles Taylor suggests, is "not simply cinephilia." Reacting to some of the moral outrage which has assailed Tarantino's film, Taylor argues that "movies have forever altered our view of the Second World War. And Tarantino is trying to shock us into realizing how clean those fantasies still are."128 Indeed, Inglourious Basterds has come under attack from certain prominent critics on shockingly flimsy moral grounds. When David Denby complains that "by making the Americans cruel, too" Tarantino "escapes the customary division of good and evil along national lines, but he escapes any sense of moral accountability as well" because "in a Tarantino war, everyone commits atrocities,"129 Taylor counters, "But in a real war, everyone commits atrocities, the Allied forces in the Second World War included. So

\footnotetext{
${ }^{125}$ Foundras 32.

${ }^{126}$ Walters 22.

${ }^{127}$ Walters 19.

${ }^{128}$ Taylor 104.

${ }^{129}$ Denby, David. "The Current Cinema: Americans in Paris: Inglourious Basterds and Julie \& Julia." The New Yorker. 24 Aug 2009, 27 Nov 2010: <<http://www.newyorker.com/arts/critics/cinema/2009/08/24/090824crci_cinema_denby >>.
} 
what is bothering Denby — that Tarantino is straying from history or that the kind of history he's brought up complicates things?"130 When Jonathan Rosenbaum laments that "For me, Inglourious Basterds makes the Holocaust harder, not easier to grasp—as a historical reality, I mean, not as a movie convention," ${ }^{131}$ Taylor readily answers that "art should make the Holocaust harder to grasp, should place the Nazis in the realm of the irrational where they belong." 132 And indeed, when Kim Newman quips that "for all its gore, this sticks to the long-running movie double standard that killing Nazis is basically harmless fun" ${ }^{\prime 33}$ it flies blatantly in the face of the evidence that is readily available in the film itself.

While acknowledging and banking on the fact that there is inherent pleasure to be derived from the depiction of the killing of Nazis, Tarantino simultaneously complicates that pleasure. While certainly not shirking away from the evil deeds the Nazis committed, Tarantino also presents the audience with German characters who are undeniably appealing. As Tarantino says:

But there's my portrayal of the German sergeant. He's not a cringing coward. He's very brave. He's actually heroic if you consider his point of view on the subject. So I'm not making it easy for you. And I never make it easy in this movie. You can enjoy what the Basterds are doing, and I set it up for you to enjoy it. But I don't make it that easy. ${ }^{134}$

Added to this complication is particularly sobering commentary Tarantino provides on the double-edged nature of the enjoyment of cinematic violence. During the screening of Nation's Pride a violent film in which hundreds of American soldiers are killed,

\footnotetext{
${ }^{130}$ Taylor 104.

${ }^{131}$ Rosenbaum, Jonathon. "Some Afterthoughts about Tarantino." JonathanRosenbaum.com. 27 Aug 2009, 27 Nov 2010: 《 http://www.jonathanrosenbaum.com/?p=16606»>.

132 Taylor 106.

${ }^{133}$ Newman 73 .

${ }^{134}$ Tarantino Interview. Sight \& Sound: 19.
} 
Tarantino depicts the "packed house of Nazi elites, including der Fuhrer and Reichsminister Goebbels," Thomas Doherty suggests, as being "like a raucous crowd of Tarantino-istas." 135 Indeed, as Ben Walters argues, "only a thoughtless viewer will not see him or herself reflected in shots of Hitler cackling as he watches Americans being slaughtered in Nation's Pride," who admits, "I was almost as horrified by the pleasure Hitler took in death-asentertainment as I was by the realization that I, myself, had been cheering on the Basterds' own brand of violence for nearly two hours."137 Again, the power of film is indiscriminate.

Ultimately, Inglourious Basterds is both Tarantino's complex meditation upon his own cinephilia and, as Gareth Higgins says, a film that "invites us to re-examine our attitudes to war and representation of violence in entertainment."138 This film, with which Tarantino "is both applauding and critiquing the power and danger of art, and confronting us—an audience that might like to think of itself as "civilised"-with our own tendency to slip into violence, ${ }^{\prime 139}$ could have come from no other filmmaker, and yet, although David Bordwell is certainly correct in his suggestion that Inglourious Basterds "exploits" Tarantino's "strengths in fresh but recognizable ways," ${ }^{140}$ it is also a film he could not have made until now. It is the fruition of nearly two decades of filmmaking fuelled by a passionate love of the cinema, and the culmination of a 12 year period in which that passion has manifested itself stylistically in progressively more

\footnotetext{
${ }^{135}$ Doherty 60.

${ }^{136}$ Walters 22.

${ }^{137}$ Biswas-Diener, Robert. "Revenge Fantasies." PsycCRITIQUES. Oct 21, 2009, Vol. 54, No. 42.

${ }^{138}$ Higgins, Gareth. "Representations of War." Soujourners. Dec 2009, Vol. 38, No. 11: 47.

${ }^{139}$ Higgins 47.

${ }^{140}$ Bordwell.
} 
complex and fascinating ways. Inglourious Basterds is a bold grappling with and thoughtful consideration of, by Tarantino, not only his cinephilia, but also of the cinema itself, including his own. 


\section{Chapter Five: Concluding Remarks - Love, Cinema, and Future Study}

The preceding chapters have set about the task of engaging with the work of a singularly fascinating filmmaker, a filmmaker whose oeuvre provides particularly fruitful terrain for the type of study into film style and cinephilia which I have here undertaken. While acknowledging that Tarantino's work has always been informed by his cinephilia, Jackie Brown was chosen as the starting point of this project because it represents something of a turning point in the director's career. No longer satisfied with simply referencing favourite films, filmmakers, and stars through dialogue and winking homage, it is here that Tarantino first manifests his love of the cinema primarily on the level of style. This idea of stylistic evocation is expanded a thousand fold in Kill Bill with the introduction of the aesthetic of acquisition. Where Jackie Brown stylistically expresses the director's love for blaxploitation cinema without employing blaxploitation style, Kill Bill pays tribute to a veritable smorgasbord of films, genres, and filmmakers by adopting specific styles and techniques from said films and reappropriating them towards Tarantino's ends. While one of these ends in Kill Bill is an interest in the power of cinema, this topic is far more fully explored in the final film chosen for this project, Inglourious Basterds. This, the director's most recent work, is the culmination of the increasingly cinephilic character of Tarantino's films of the past 13 years, beginning with Jackie Brown. Featuring an unprecedented diegetization of the director's love for the cinema, Inglourious Basterds is both Tarantino's most complex and sophisticated meditation on his own cinephilia, and his thoughtful consideration of the double-edged nature of the power of cinema. 
It is, perhaps, fitting that it is with Inglourious Basterds--this culminating moment in the manifestation of his cinephilia - that Tarantino takes on as a central concern the cinema itself, its power and the nature of the pleasure it provides. Revealed here is an interesting and paradoxical fascination/repulsion dynamic on Tarantino's part, with regard to the cinema, that carries with it intriguing potential implications for the rest of the director's work. Frequently put forth as a target for moral outrage due to the graphically violent content of his films, it is a fascinating irony that Tarantino may now be revealing himself as something of a moralist. Tarantino celebrates the cinema's unique capacity for displaying the human form, while simultaneously coming to terms with the frequent cinematic practice of portraying the graphic destruction of that form, as well as the fact that there is a certain perverse pleasure to be had from watching that destruction. It appears that Gareth Higgins' statement that Inglourious Basterds “invites us to re-examine our attitudes to war and representation of violence in entertainment,",141 may well extend beyond this particular film. Perhaps, this is what Tarantino has been cinephilically driven to do all along.

In my introduction I distinguish between conventional views of cinephilia, and the contemporary brand which has arisen since Susan Sontag's proclamation of its death in 1996. Tarantino has proven to be a particularly useful subject for my analysis, in part, because of the heightened nature of his cinephilia relative to previous cinephilic filmmakers. Martin Scorsese may speak of the manner in which, for his generation of filmmakers emerging in the 1960s and 1970s, a lifetime of loving and watching films has defined the way they see and make movies, resulting in "a way of writing with the

\footnotetext{
${ }^{141}$ Higgins, Gareth. "Representations of War." Soujourners. Dec 2009, Vol. 38, No. 11: 47.
} 
camera that stays in your mind, ${ }^{, 142}$ but this is an exponentially more present reality for Tarantino. He is the most famous example in the world of the "new generation of equally devoted cinephiles who display and develop new modes of engagement with the overabundance of cinematic material widely available through advanced technology,"143 described by Marjike de Valck and Malte Hagener, and this is manifest in the explicitness the cinephilia evident in his work. The fact of his having come of age as a cinephile during the era of video and its subsequent iterations in DVD and Blu-ray cannot be overemphasized. Indeed, the sheer volume and variety of his exposure to the cinema, a volume and variety impossible before the advent of home video, is amongst the most significant causal factors behind this most explicitly cinephilic of filmmakers.

The resurgence of cinephilia at this contemporary moment, as exemplified by the almost unprecedented degree to which Quentin Tarantino's filmmaking has been informed by his cinephilia, has afforded me the opportunity, in this study, to grapple with the remarkable ways in which the abstraction of love can come to be manifested in the concreteness of artistic technique. This seems to me a worthy endeavour, both within the context of the historiography of film style and within the broader project of the historical poetics of style, described in Bordwell's Poetics of Cinema as a project which, "investigates how film artists, as historical agents, work within the zones of choice and control offered by their circumstances."144 Perhaps more so than any other filmmaker, the circumstances that define the zones of choice and control in Tarantino's filmmaking

\footnotetext{
${ }^{142}$ Ebert, Roger. "Scorsese Learns from Those Who Went before Him." Scorsese by Ebert. The University of Chicago Press, Chicago, 2008: 219.

${ }^{143}$ Valck, Marjike de and Malte Hagener. "Down with Cinephilia? Long Live Cinephilia? And Other Videosyncratic pleasures." Cinephilia: Movies, Love and Memory. Amsterdam University Press, Amsterdam, 2005:12-13.

${ }^{144}$ Bordwell, David. Poetics of Cinema. New York: Routledge, 2008: 54.
} 
are provided by the cinema itself, and his love for it. Indeed, although my project is consistent with the tenets of piecemeal history in that it rejects the concept of a single essence of cinema as conceived in the Standard, Dialectical and Oppositional programs of film style historiography discussed in chapter 1 , I think it reasonable to suggest that the artistic manifestation of love may well be the essence of Tarantino's cinema.

If I may be so bold, I would like to suggest that Tarantino is hardly alone in this. Indeed, although the environment of heightened cinephilia out which Tarantino emerges marks him as a truly useful case study with which to explore the implications of cinephilia on the practice of filmmaking, I would like to suggest that the history of filmperhaps more frequenting now, but certainly throughout the past 50 years of cinema and beyond-is filled with artists whose work, to one degree or another, is bound up in an affection for the films and filmmakers that have come before, and, indeed, in an affection for film itself. Tarantino was selected for this project due to the very explicit manner in which he exemplifies this suggestion, but I could choose any number of other filmmakers as the focus of future cinephilically focused work. Examples that come to mind include, but are certainly not limited to, Jean-Luc Godard, Martin Scorsese, Brian De Palma, and Paul Thomas Anderson. In sum, with respect to the question of how cinephilia can become manifest at the level of film style, the terrain is ripe for much fruitful work to be done concerning how the love of cinema can serve as an engine for artistic expression. 


\section{List of Figures and Captions:}

Fig. 2.1 The opening shot of Jackie Brown 19

Fig. 2.2 Low angle tracking profile shot of Pam Grier 20

Fig. 2.3 ‘Roman’ Profile close-up of Pam Grier 22

Fig. 2.4 Two minute tracking shot of hurried Pam Grier 27

Fig. 3.1 First onscreen appearance of Bill (David Carradine) 35

Fig. 3.2 Gordon Liu in "The Cruel Tutelage of Pai Mei” chapter 39

Fig. 3.3 Single image invocation/fusion of disparate film styles 44

Fig. 3.4 Cinemetric analysis of final gunfight in The Good, the Bad and the Ugly 46

Fig. 3.5 Cinemetric analysis of the Samurai duel in Kill Bill: Vol. 1

Fig. 3.6 Single scene synthesis of disparate film styles 49

Fig. 3.7 Tarantino visually celebrates his actress and his medium $\quad 51$

Fig. 4.1 Isolated Inglourious Basterds setting evokes spaghetti westerns $\quad 54$

Fig. 4.2 First chapter of Inglourious Basterds is devoted to Col. Hans Landa 57

Fig. 4.3 Tarantino diegetizes his love for the cinema $\quad 59$

Fig. 4.4 Tarantino celebrates Josef von Sternberg with a surrogate Marlene Dietrich 63

Fig. 4.5 Tarantino's camera celebrates the warrior Shosanna 65

Fig. 4.6 Shosanna's image projected in smoke $\quad 69$ 


\section{Bibliography}

Astruc, Alexandre. "The Birth of a New Avant-Garde: La Camera Stylo." The New Wave. London: Secker \& Warburg, 1968.

Baxandall, Michael. "Excursus Against Influence." Patterns of Intention: On the Historical Explanation of Pictures. New Haven: Yale University Press, 1985

Bazin, Andre. What Is Cinema? Berkley: University of California Press, 1967.

Biswas-Diener, Robert. "Revenge Fantasies." PsycCRITIQUES. Oct 21, 2009, Vol. 54, No. 42.

Bordwell, David. “(50) Days of summer (movies), Part 2." Observations on Film Art. 12 Sept 2009, 27 Nov 2010: < http://www.davidbordwell.net/blog/?p=5446>>.

Bordwell, David. On The History of Film Style. Cambridge, Massachusetts: Harvard University Press, 1997.

Bordwell, David. Poetics of Cinema. New York: Routledge, 2008.

Brown, Dave. "Tarantino and the Re-Invention of the Martial Arts Film." Metro. 2006: No. 148.

Carradine, David. Interview for "The Making of Kill Bill: Vol. 2." Kill Bill: Vol. 2 DVD. Alliance Atlantis, 2004.

Dargis, Manohla. “The $21^{\text {st }}$ Century Cinephile.” New York Times, 14 November 2004, late final edition

De Baecque, Antoine. "The Disillusioned Enthusiasm of Quentin Tarantino: A Reflection on Jackie Brown." Jackie Brown: Collector's Edition DVD. Alliance Atlantis Communications Inc., Canada, 2002. Translated and Expanded from "Jackie Brown." Cahiers du Cinema, April 1998, Vol. 523.

Denby, David. "The Current Cinema: Americans in Paris: Inglourious Basterds and Julie \& Julia." The New Yorker. 24 Aug 2009, 27 Nov 2010: $<<$ http://www.newyorker.com/arts/critics/cinema/2009/08/24/090824crci_cinema -denby $>$.

Denby, David. "The Moviegoers." The New Yorker, 6 April 1998, pp. 94-101.

Doherty, Thomas. "Inglourious Basterds." Cineaste. Winter 2009. 
Duncan, Theresa. "Twin Bills." Artforum International. Feb 2004: Vol. 42, No. 6.

Ebert, Roger. "Scorsese Learns from Those Who Went before Him." Scorsese by Ebert. The University of Chicago Press, Chicago, 2008.

Emerson, Jim. "Cutting the Basterds." Scanners :: Blog. 2 Oct 2010, 27 Nov 2010: <<http://blogs.suntimes.com/scanners/2010/10/cutting_the_basterds.html $>$.

Foundras, Scott. "Kino Über Alles.” Film Comment. July/Aug 2009: Vol. 45, No. 4.

Gallafent, Edward. Quentin Tarantino. Harlow, England: Pearson Education Limited, 2006.

Gilbey, Ryan. "Quentin Tarantino: The Golden Boy Must Make Good.” The Observer. May 3, 2009.

Hampton, Howard. “Extreme Prejudice.” Film Comment. Nov/Dec 2005: Vol. 41, No. 6.

Higgins, Gareth. "Representations of War." Soujourners. Dec 2009, Vol. 38, No. 11.

James, Nick. "Carve His Name With Pride." Sight \& Sound. July 2009: Vol. 19, No. 7.

Jones, Kent. "Critic's Heart is an Ocean of Longing: Après-Christmas Grumblings." Film Comment. Mar/Apr 1998; Vol. 34, No. 2.

Kauffmann, Stanley. “A Lost Love?” The New Republic, 9 August 1997.

Keathley, Christian. "The Cinephiliac Moment." Framework, 42 (summer 2000) <http://www.frameworkonline.com/Issue42/42ck.html> (visited 26 Aug. 2010).

Keathley, Christian. "The Cinephiliac Moment and Panoramic Perception." Cinephilia and History, or the Wind in the Trees. Indiana University Press, Bloomington and Indianapolis, 2006: 33.

Leonard, Elmore. "A Letter From Elmore Leonard." Jackie Brown Collector's Edition Booklet. Alliance Atlantis Communications Inc., Canada, 2002.

Miklitsch, Robert. "Audiophilia: Audiovisual Pleasure and Narrative Cinema in Jackie Brown." Screen. Winter 2004, Vol. 45 Issue 4.

Newman, Kim. "Inglourious Basterds." Sight \& Sound. Sept 2009: Vol. 19, No. 10.

Newman, Kim. "Kill Bill Vol. 1: Review." Sight \& Sound. Dec 2003: No. 12. 
$\mathrm{Ng}$, Jenna. "Love in the Time of Transcultural Fusion: Cinephilia, Homage and Kill Bill." Cinephilia: Movies, Love and Memory. Amsterdam University Press, Amsterdam, 2005.

Norris, Chris. "Mixed Blood." Film Comment. Nov/Dec 2003: Vol. 39, No. 6.

O’Brien, Geoffrey. “Devotional Furies.” Film Comment. Nov/Dec 2003: Vol. 39, No. 6.

Peary, Gerald. Quentin Tarantino: Interviews. University Press of Mississippi, Jackson, 1998

Rosenbaum, Jonathon. "Some Afterthoughts about Tarantino." JonathanRosenbaum.com. 27 Aug 2009, 27 Nov 2010: $<<$ $\mathrm{http}: / / \mathrm{www}$.jonathanrosenbaum.com/?p=16606>>.

Salt, Barry. Moving Into Pictures: More on Film History, Style, and Analysis. London: Starword, 2006.

Schivelbusch, Wolfgang. The Railway Journey. University of California Press, Berkeley, 1986.

Sontag, Susan. "The Decay of Cinema." New York Times, 25 February 1996, late final edition.

Scott, Tony. True Romance. Morgan Creek Productions, 1993.

Tarantino, Quentin. Inglourious Basterds. Alliance Films, 2009.

Tarantino, Quentin. Interview for “The Making of Kill Bill: Vol. 1." Kill Bill: Vol. 1 DVD. Alliance Atlantis, 2004.

Tarantino, Quentin. Interview for "The Making of Kill Bill: Vol. 2." Kill Bill: Vol. 2 DVD. Alliance Atlantis, 2004.

Tarantino, Quentin. "Interview - Quentin Tarantino on His Movie Influences." Hollywood Teamster. 16 Feb 2010, 27 Nov 2010: $<<$ $\mathrm{http} / / /$ moviedriver.wordpress.com/2010/02/16/interview-quentin-tarantino-on-hismovie-influences/ $>$.

Tarantino, Quentin. Interview with Adrian Wooten. The Guardian. 5 Jan. 1998, 23 Oct. 2010: $<$ http://www.guardian.co.uk/film/1998/jan/05/quentintarantino.guardianinterview satbfisouthbank $1>$. 
Tarantino, Quentin. Interview with Michel Ciment and Hubert Niogret. Positif. April, 1998, Vol. 446.

Tarantino, Quentin. Interview with Ryan Gilbey. "Days of Gloury." Sept 2009: Vol. 19, No. 9.

Tarantino, Quentin. Kill Bill: Vol. 1. Alliance Atlantis, 2003.

Tarantino, Quentin. Kill Bill: Vol. 2. Alliance Atlantis, 2004.

Tarantino, Quentin. Reservoir Dogs. Live Entertainment, 1992.

Taylor, Charles. "Violence as the Best Revenge." Dissent. University of Pennsylvania Press: Winter 2010, Vol. 47, No.1: 105.

Valck, Marjike de and Malte Hagener. "Down with Cinephilia? Long Live Cinephilia? And Other Videosyncratic pleasures." Cinephilia: Movies, Love and Memory. Amsterdam University Press, Amsterdam, 2005.

Walters, Ben. "Debating Inglourious Basterds." Film Quarterly. Winter 2009-2010: Vol. 63, No. 2.

Welles, Orson and Bogdanovich, Peter. This is Orson Welles. Da Capo Press, New York, 1998.

Willemen, Paul. "Through the Glass Darkly: Cinephilia Reconsidered." Looks and Frictions: Essays in Cultural Studies and Film Theory. Indiana University Press, Bloomington and Indianapolis, 1994. 